\title{
A statistical approach to relationships between fluid emissions and faults: The Sea of Marmara case
}

\author{
Henry P. ${ }^{1,{ }^{*}}$, Grall Celine ${ }^{2}$, Kende Julia ${ }^{1}$, Viseur S. ${ }^{1}$, Özeren M.S. ${ }^{3}$, Şengör A.M.C. ${ }^{3}$, \\ Dupré Stephanie ${ }^{4}$, Scalabrin Carla ${ }^{4}$, Géli Louis ${ }^{4}$
}

${ }^{1}$ Aix Marseille Univ, CNRS, IRD, Coll France, CEREGE, Aix-en-Provence, France

${ }^{2}$ Lamont-Doherty Earth Observatory of Columbia University, Palisades, NY, USA

${ }^{3}$ Istanbul Technical University, Eurasia Institute of Earth Sciences, 34469, Maslak, Istanbul, Turkey

${ }^{4}$ IFREMER, Département Ressources physiques et Ecosystèmes de fond de Mer (REM), 29280

Plouzané, France

*Corresponding author : P. Henry, email address : henry@cerege.fr

\begin{abstract}
:
The Sea of Marmara is traversed by the North Anatolian Fault system and also presents abundant emission sites of methane gas into the water column. In order to assess the spatial relationship between gas emissions and active faults, the distribution of distances between gas emission sites and the nearest fault is calculated and compared with the distribution of distances between a uniform random distribution of points (Poisson process representing the null hypothesis of an absence of relationship between gas emissions and faults) and the nearest fault. Interestingly, the distance distribution for the Poisson process is nearly exponential, indicating that the fault map does not have a characteristic scale other than that representing the intensity of the fault network. The distance distribution for the observed gas emissions is significantly narrower than that arising from the Poisson process, with a Kolmogorov distance of $0.25 \pm 0.02$. The crossing point between the two distributions defines the characteristic halfwidth of the swath of gas emission sites around the mapped active faults. For the whole Sea of Marmara data set a characteristic half-width of $900-1000 \mathrm{~m}$ is found which matches the half-width of the seafloor deformation zone observed around the main active fault. When the same analysis is applied to zones covering the Western High and the Central High it is found that the swath of gas emissions is wider on the Central High ( $2 \mathrm{~km}$ half-width), and not clearly related to the seafloor deformation zone there. This difference is put in perspective with recent work showing that creep is occurring on the western segment of the Main Marmara Fault (this also causing microseismicity) while the central Istanbul-Silivri segment may have remained locked since the 1766 magnitude 7+ earthquake. This suggests that aseismic slip (and not only earthquake occurrence) effectively maintains high permeability conduits in fault zones in sediments.
\end{abstract}

Keywords : cold seeps, gas emissions, transform plate boundary, strike-slip fault, damage zone 


\section{Introduction}

Faults zones are potential conduits for fluid migration and are known to influence the distribution of fluid emissions (cold seeps) at the seafloor in tectonically active settings (e.g. Barnes et al., 2010; Bohrmann et al., 2002; Henry et al., 1989; Kobayashi, 2002; Le Pichon et al., 1992; Moore et al., 1990; Orange et al., 2002; Sibuet et al., 1988; Zitter et al., 2008) as well as in areas affected by gravity-driven structure generation (e.g. Gay et al., 2007; Loncke et al., 2004) and mud or salt diapirism (e.g. Chamot-Rooke et al., 2005; Hovland, 2002; Medialdea et al., 2009). Gas emission sites are known to be self-sealing, with an evolution in the course of several years to tens of years from continuous bubble emissions, to intermittent through bacterial mats, to no emission when gas is retained beneath carbonate crusts and oxidized in the sediment (Hovland, 2002). Moreover, the intensity of fluid emissions associated with active faults may depend on past seismic activity (or creep) and could thus provide useful indications for earthquake hazard assessment (Dupré et al., 2015; Geli et al., 2008). While large scale maps leave little doubt that faults and folds have an influence on the distribution of manifestations of fluid emissions at the seafloor, detailed studies of the structural and geomorphological context of seeps conclude that relationships can be complex at the scale of a few tens to hundreds of meters (Henry et al., 2002; Lallemand et al., 1992). Seepage mapping efforts first relied on manned submersible dives, camera tracks, and remotely operated vehicle surveys, making the acquisition of an unbiased representation of seep distribution a slow and difficult process. This limited the usability of statistical approaches in studies of relationships between faults and cold seeps. However, Paull et al. (2005) used a large data set from ROV dives in the Bay of Monterey to show that erosion is the main factor controlling cold seep distribution there, in spite of the presence of several seismically active strike-slip faults, and to challenge the view that chemosynthetic communities need a flux of fluid through the seafloor to thrive. Over the last ten years, our ability to detect gas emissions in the water column has been greatly improved with modern 


\section{ACCEPTED MANUSCRIPT}

multi-beam sounders allowing to routinely log water column echoes (Augustin, 2011). The water column imagery, previously restricted to small volumes of insonification, commonly acquired with the use of single beam (Dupré et al. 2014; Greinert et al. 2006; Sund, 1935) and side scan sonars (Dupré et al. 2010; Klaucke et al. 2006; Merewether et al. 1985), now beneficiated from large 3D datasets acquired in relatively short periods. For instance, an EM302 multi-beam survey in the Sea of Marmara during Marmesonet cruise of R/V Le Suroit provided a nearly continuous and uniform coverage of acoustic anomalies in the water column, indicative of gas emissions at the seafloor (Dupré et al., 2015). These acoustic anomalies of the Marmesonet dataset are mainly caused by the impedance contrast between the gas bubbles and the surrounding water. The relatively few anomalies attributed to the contrast between swim bladders of fishes and surrounding water have been removed. A relationship appears on the larger scale when the acoustic anomaly map is overlaid on a map of active faults (Dupré et al., 2015; Sengör et al., 2014) but, again, this relationship is far from being systematic and appears complex when zooming to the scale of Autonomous Underwater Vehicle (AUV) surveys and manned submersible observations (Grall et al., this issue). Moreover, if gas is trapped in sediments (consolidated or not), any avenue to the surface would trigger seepage and faulting (and indeed jointing) is an excellent way of providing such avenues.

We here apply a statistical approach to the Sea of Marmara data set to test the hypothesis of a relationship between seeps and active faults. Key questions are whether the seep-fault relationship is governed by a characteristic length-scale and, to which extent the characteristics of the fault network influence the distribution of seeps. We show that segments of the major faults are associated with a seafloor deformation zone and compare its width with that of the swaths of gas emissions. While some general conclusions appear reachable, there are also differences between adjacent fault segments in the Sea of Marmara. We propose to relate these differences to the locked or creeping behavior of the fault segments, as inferred from geodetic and seismic studies.

\section{Sea of Marmara data sets}

The acoustic anomaly detection performed on EM302 data by manual picking (Dupré et al., 2015) yielded a population of more that 200000 anomaly picks, which includes an important fraction of redundant picks. Considering that the footprint of the gas plumes is $100 \pm 50 \mathrm{~m}$ radius taking into account data resolution and uncertainty of manual picking, the acoustic anomaly picks may be grouped in arbitrary 100 by $100 \mathrm{~m}$ zones. Most zones contain 


\section{ACCEPTED MANUSCRIPT}

less than 5 picks but some contain several hundreds to several thousand picks. These high numbers result from analyzing data acquired while the ship was in station or moving very slowly. In order to keep the exact location of isolated acoustic anomalies while removing redundant picks; a flexible binning recursive algorithm was applied. For each acoustic anomaly, anomalies within $50 \mathrm{~m}$ distance east and north were replaced with a single data point having the mean coordinates of the group, and the group was then removed from the list. This re-sampled population is reduced to about 6500 acoustic anomalies having a minimum spacing of $50 \mathrm{~m}$ (Figure 1).

The acoustic survey coverage is continuous in its central part where data were acquired on parallel profiles spaced $800 \mathrm{~m}$, but gaps are apparent where tracks are more widely spaced. The width of the zone where gas plumes can be detected is in general smaller than the width of the bathymetric swath because the specular reflection on the seafloor near the center of the swath causes noise on the external beams (Figure 2). The detection depends on the size of the gas plume size, water depth, and backscatter intensity. As a general rule, gas plume detection has been effective up to $600 \pm 200 \mathrm{~m}$ from the ship track. In the following, an average value of $600 \mathrm{~m}$ is retained for the detection range.

The active fault map used (Sengor et al., 2014) is based on a critical review of maps of the Marmara fault segments (e.g. Armijo et al., 2002; Becel et al., 2010; Carton et al., 2007; Demirbağ et al., 2003; Grall et al. 2012; Imren et al., 2001; Le Pichon et al. 2001; Parke et al., 2001, 1999; Rangin et al. 2004; Sorlien et al. 2012) using a database of 210 multichannel seismic as well as high-resolution bathymetry and chirp profiles reported in the literature (Figure 3). Care was taken to distinguish active faults causing offsets within the recent sediments and buried faults, which may be interpreted as inactive faults or as blind faults with uncertain activity (Sengor et al., 2014). In the analysis of relationships between faults and gas plumes, we only retain the faults classified as active (Figure 4). This fault map was mostly drawn based on interpretations of multichannel seismic profiles and, in some areas, the fault drawing is improvable as it could follow more precisely the morphological scarps observed at the seafloor. However, we consider that this map is accurate enough to evaluate the relationship between acoustic emissions and faults at the scale of the Sea of Marmara, also keeping in mind that the acoustic anomaly map has a resolution of $\approx 100 \mathrm{~m}$.

\section{Statistical data analysis and results}

\subsection{Bulk analysis of Sea of Marmara data}




\section{ACCEPTED MANUSCRIPT}

The minimum distance to the nearest fault was calculated for each acoustic anomaly in the Sea of Marmara. For comparison, the null hypothesis of no relationship between cold seeps and faults may be modeled as a random distribution with uniform probability of occurrence over the study area (Poisson process). In order to account for the actual coverage of the acoustic survey, a mask is applied to the random distribution to exclude points located more than $600 \mathrm{~m}$ from the ship track, corresponding to the average half-width of the zone where acoustic anomalies could be detected (Figure 4B). Hence, in this masked distribution, ship tracks are apparent where their spacing is more than $1200 \mathrm{~m}$. The minimum distance distribution for this uniform distribution is calculated using the same algorithm as for the real data. The resulting minimum distance histograms and cumulative distribution functions are shown in figures 5 and 6 . The mean distance to the nearest fault is $1.38 \mathrm{~km}$ for the acoustic anomalies, and $2.2 \mathrm{~km}$ for the random distribution. The medians are respectively $0.72 \mathrm{~km}$ and $1.5 \mathrm{~km}$. The medians are thus smaller than the means, and it appears that the distributions do not follow normal distributions but have larger tails. The mean vs. median ratio is also larger for the acoustic anomaly distribution than for the random distribution. This is in part because of an important population of acoustic anomalies at about $6 \mathrm{~km}$ from the nearest faults (Figure $5 \mathrm{~A}$ ). Most of those anomalies are along the NW and $\mathrm{N}$ edge of the Tekirdag Basin (see Figures 3 and 4A), and gas emissions align there although no active fault was mapped (Dupré et al., 2015). Most studies consider that the NW edge of Tekirdağ is tectonically active only near its western end, where a transpressive fault following the basin edge connects with the main fault (Armijo et al., 2002, Rangin et al., 2004, Grall et al., this issue). Explaining the concentration of gas seeps further NE along the base of the scarp requires taking into account the sedimentary structure.

Considering the large size of the populations (more than 6500) and applying, for instance, a Kolmogorov-Smirnov test, it appears almost certain that the acoustic anomaly distribution is statistically different from a uniform random one ( $\mathrm{p}$-value $<10^{-6}$ ). Faults thus do influence the distribution of seeps. The Kolmogorov distance is generally defined as the absolute value of the maximum difference between two cumulative distribution functions. As the populations are set equal, the difference between the cumulative distributions is maximum at the crossing point of the histograms (Figure 5), and the area between the histograms integrated on either side of the crossing point and normalized to the population size is equal to the Kolmogorov distance. The Kolmogorov distance between the randomly generated and observed distributions thus provides an indication of the minimum number of acoustic anomalies that would need to be moved to match the observed distribution with the random 


\section{ACCEPTED MANUSCRIPT}

one, and this fraction is $0.25 \pm 0.02$. This value, however, underestimates the total number of gas emission sites that are influenced by faults. This is because it can be suspected that a proportion of seepage sites close to a fault would be physically or chemically influenced by fluid migration in the fault zone even in the theoretical case when the spatial distribution would be uniform.

The distribution of minimum distances in the uniform random (null) case is a function of the properties of the fault network. If faults were parallel and regularly spaced, the minimum distance distribution would be uniform and range between 0 and half of the distance between faults, with mean and median distances both equal to $1 / 4$ of the distance between faults. In fact, the distance distribution can be approximated as an exponential (Figure 6). An exponential nearest neighbor distribution $D(d)$ with parameter $2 \lambda$ is expected for a 1-D Poisson point process of intensity $\lambda$ (e.g.: Baddeley, 2007)

$$
D(d)=1-\mathrm{e}^{-2 \lambda d}
$$

where $D$ is the probability that the nearest neighbor is at a distance smaller than $d$ from a given point. A random distribution of parallel faults may be modeled as a 1-D Poisson point process. In this particular case, the intensity of the fault network (length of fault per surface area) would also be equal to $\lambda$ and the average spacing between faults would be $1 / \lambda$. The parameter of the exponential distribution is $2 \lambda=4.3510^{-4} \mathrm{~m}^{-1}$ and matches the $2.2 \mathrm{~km}$ mean distance to faults previously determined for the uniform random distribution. It also matches the intensity of the fault network (determined independently as length of fault per surface area), $2 \pm 0.510^{-4} \mathrm{~m}^{-1}$ in the survey area. The distribution of minimum distances in the uniform random (null) case is thus found to be compatible with a 1-D Poisson point process. This suggests that the fault network drawing used is not strongly correlated spatially, at least in the $100 \mathrm{~m}$ to $10 \mathrm{~km}$ scale of the data sets, and that its only characteristic length scale $1 / \lambda \approx 4.6 \mathrm{~km}$ may be interpreted as the average spacing between faults. As the faults have a dominant E-W orientation, it should be understood that this conclusion only applies when examining the distribution of faults along a N-S transect. Considering now that acoustic anomalies located closer from a fault than half the average spacing between faults (about $2.2 \mathrm{~km}$ ) may hypothetically be influenced by fluid flow along this fault, the maximum fraction of the gas emissions hypothetically influenced by faults could be as high as $80 \%$.

\subsection{Zoned analysis}

A bulk analysis of the data set indicates that acoustic emissions are significantly closer to faults than if they were randomly distributed. Examination of specific zones provides a 
clearer view of the length scales involved. In the following we will examine acoustic anomaly distributions in two zones in the Sea of Mamara (over the Western High and Central High) and compare them with uniform random distributions generated over the surveyed parts of the same zones. The partial probability distributions of distances obtained for random uniform cases are similar in shape to the overall probability distribution (Figure 5). The partial probability distributions can also be approximated as exponentials with slightly smaller distance parameters $1 / 2 \lambda$, about $1.6 \mathrm{~km}$ for the Western High box and $2.1 \mathrm{~km}$ for the Central High box. These smaller values are largely due to the clipping of the tail of the distance distribution by the dimensions of the box. Only the overall cumulative distribution is shown on Figure 6 for the random uniform case. A large part of the gas emission activity on the Western High is found in a swath along the Main Marmara Fault (Dupré et al., 2015; Geli et al., 2008; Zitter et al., 2008). A Western High zone is defined encompassing the Western High and adjacent areas of the Tekirdag and Central Basins (Figure 4). The distribution of distance to the nearest fault in this zone is narrower than for the bulk data set, with mean and median respectively $742 \mathrm{~m}$ and $525 \mathrm{~m}$. The distribution is not exponential as the histogram is flat from 0 to $600 \mathrm{~m}$ and marks a step between $600 \mathrm{~m}$ and about $1000 \mathrm{~m}$ (Figure 5). This supports visual interpretations of maps showing that seeps associated with the main active faults in this area are found in a swath along the faults of 600 to $1000 \mathrm{~m}$ (Dupré et al., 2015; Grall et al., this issue). The square shape of the distribution may also be linked with the observation that relatively few manifestations of fluid emissions are found on the main fault trace while minor structures within a broader deformation zone play an important role (Grall et al., this issue). The same rules and length scales apply to seeps associated with faults in the deep basins (Tekirdag, Central and Cinarcik basins). The distribution of distance to fault for acoustic anomalies in the Western High zone is compared with that of the same number of uniformly distributed points in Figure 5B. The partial probability distributions of distances obtained In the Western High zone, the crossing point between the distributions is $910 \mathrm{~m}$ and the difference between the observed and random cumulative distribution reaches a maximum of $0.36 \pm 0.03$ (the Kolmogorov distance) at this point. We will retain $910 \mathrm{~m}$ as defining the half-width of the swath of seep activity associated with faults in the Western High area. The fraction of gas emissions within this swath is about $75 \%$.

On the broad topographic high between the Central Basin and the Cinarcik Basin, the relationship between faults and acoustic emissions is not as clear as on the Western High. It has been reported that segments of the Main Marmara Fault there have few seeps along their seafloor trace (Dupré et al., 2015; Géli et al., 2008). Our analysis shows the distribution of 


\section{ACCEPTED MANUSCRIPT}

distance to the nearest fault is broader than for the whole Marmara dataset (Figure 5C and 6), with mean and median values respectively 1.3 and $1.0 \mathrm{~km}$. The observed distribution does not follow an exponential distribution and the difference between the observed and random cumulative distribution functions reaches a maximum of 0.22 at $2080 \mathrm{~m}$ (the Kolmogorov distance is thus $0.22 \pm 4$ )(Figure 6). The distance histogram shows a first step at $1200 \mathrm{~m}$ and a larger one at 2000-2100 m (Figure 5c). The first step could correspond, like in the Western High zone, to swaths of acoustic emission along active faults. These for instance are observed on fault segments between the Central Basin and the Kumburgaz Basin. The second step is in part caused by the intense activity in the Central High summit area, a broad antiform hosting widespread gas emission between the fault zone and $2 \mathrm{~km}$ southward (Figure 4) (Dupré et al., 2015; Grall et al., this issue). Gas emissions distributed on the slopes, which could be related to widespread slope creep (Shillington et al., 2012; Zitter et al., 2012), are observed at even larger distances. The statistical analysis confirms that the relationship between seeps and faults is less well defined there than in other parts of the Sea of Marmara. On the Central High, the swath of gas emissions along active faults appears broader, about $2 \mathrm{~km}$ half-width, and more than $80 \%$ of the seeps are found in these broad swaths. However, the distance to the nearest fault is here a weak criterion as the mean distance to the nearest faults for a random distribution of points, which we showed also relates with the intensity of the fault network, is also about $2 \mathrm{~km}$ in this zone. Consequently, it appears difficult to evaluate which portion of gas emissions in the Central High zone should be attributed to migration within fault zones rather than indirect effects (e.g. folding and slope instability).

\section{Seafloor deformation zones around the Main Marmara Fault and their relationship with gas emissions.}

High-resolution bathymetric data ( $2 \mathrm{~m}$ gridded maps) acquired around fault zones indicate that a zone of deformation is generally present around the main faults featuring smaller scale faults such as Riedel shears and en-echelon normal faults, folds, and small basins, indicating that some amount of deformation is distributed around the main fault traces (Grall et al., this issue). In the following, seafloor deformation zone will designate a zone associated with an active fault (possibly blind) where geomorphological indicators of strain are observed at the seafloor, that may include small folds and basins, scarps associated with small faults, and slope instabilities. The shear zone term will be used more specifically when structural evidence for shearing is found (e.g. Reidel shears or en-echelon faults). The damage zone term will be used with its generally accepted definition as a zone of brittle deformation 


\section{ACCEPTED MANUSCRIPT}

developing around principal fault planes as a consequence of fault growth, fault slip or fault interaction (Chester and Logan, 1986; Faulkner and Mitchell, 2011; Kim et al., 2004; Savage and Brodsky, 2011; Shipton and Cowie, 2001). We here display three examples of seafloor deformation zones, from the northern scarp of the Cinarcik Basin, the Western High, and the Central High (Figure 7). The maps of seafloor fault scarps shown here are based on Marmesonet AUV bathymetry (Géli et al., 2009) and supported by sediment sounder profiles, videos from manned submersible and ROV dives (Armijo et al., 2005; Grall et al., this issue; Zitter et al., 2012, 2008) and, on the Western High, by 3D high-resolution seismic data (Grall, 2013; Thomas et al., 2012). More detailed descriptions of the structural context of seepage sites are found in Grall et al. (this issue).

Along the Cinarcik Basin northern scarp, seafloor deformation is confined within a 1 to $3 \mathrm{~km}$ wide bench between the basin floor to the south and the base of a cliff of Paleozoïc sedimentary rocks. The base of the cliff is fault controlled, but this fault branch may not be currently active (Henry et al., 2007; Zitter et al., 2012). The lower slope break at the basin edge is mapped as the main fault scarp at the larger scale but in fact is generally not coincident with a seafloor rupture. Most seafloor ruptures are found in a $500 \mathrm{~m}$ to $1 \mathrm{~km}$ wide transtensional shear zone running along the edge of the bench with geometry interpretable in term of R1-shears, P-shears, en-echelon normal faults, and cusped slump scars (Figure 7B). Gas emissions are mostly found within this shear zone as well as near the bottom of the cliff, where the presence of high permeability scree is suspected (Zitter et al., 2012). No anomalies are found in the basin side. This may be explained by the very high sedimentation rate (more than $3 \mathrm{~mm} / \mathrm{yr}$; Seeber et al., 2004), which could act against the development of brittle fractures in shallow sediments (see section 5). Sedimentation rates are of the same order in the depocenters of Tekirdağ Basin, Central Basin and Kumburgaz Basin (Grall et al., 2012; Zitter et al., 2012) where vents are absent or rare (Dupré et al., 2015; Grall et al., this issue).

On the Western High, the morphological expression of the Main Marmara Fault (MMF) is expressed as a nearly continuous fault scarp. Subsidiary fault systems include sets of Riedel R1-shears crossing a pull apart-basin where the main fault marks a releasing $800 \mathrm{~m}$ step-over, and an array of normal faults extending from the summit of a fault parallel anticline 500-800 m south of the fault to about $1.5 \mathrm{~km}$ north in a zone also affected by NE-SW enechelon folds and mud diapirism (Thomas et al., 2012) (Figure 7C). Strike-slip subsidiary faults, sub-parallel to the MMF, are also observed near the eastern edge of the survey area. Buried strike-slip faults 1-1.5 km south of the main active branch follow the southern side of the fault parallel anticline. They may not be active today. Normal faults found further south 
have a completely different orientation than those within the MMF deformation zone. That orientation is only compatible with slope-driven stresses. Most of the gas seeps are found within the zone of deformation of the MMF or near the top of topographic highs (or folds). The most active zone is associated with a mud injected NE-SW anticline north of the fault (near $\mathrm{x}=9 \mathrm{~km}$ ) (Thomas et al., 2012; Tryon et al., 2012).

In the Central High area, although the fault valley crossing the topographic high is also obvious on the larger scale, fault scarps do not appear as sharp as on the Western High. Around the high point, three parallel slightly undulating valleys spaced $\approx 300 \mathrm{~m}$ may be interpreted as en-echelon Reidel shears, defining a $<1 \mathrm{~km}$-wide principal shear zone (Figure 7D). The slopes are affected by creeping resulting in wavy morphology (Shillington et al., 2012; Zitter et al., 2012). The wave pattern is marked by lineaments suggesting incipient shearing up to $1.5 \mathrm{~km}$ south and north of the principal shear zone. Gas emissions are surprisingly few in the principal shear zone but concentrate on the top of the anticline and along some of the lineaments. Gas emissions are also focused along the edge of the Kumburgaz basin to the west, which does not correspond to an active fault but to a sedimentary discontinuity (Grall et al., this issue).

These examples show that it is often possible to define a seafloor deformation zone, typically of a kilometer half-width, around the MMF. Gas emissions are in large part related to these deformation zones but their distribution also depends on the context. As indicated by the statistical analysis, the width of the deformation zones appears to match that of the swath of acoustic anomalies on the Western High and along (active) basin edges, but again, the Central High displays a different behavior.

\section{Interpretation and discussion}

\subsection{Width of deformation zones around faults.}

The analysis of the Sea of Marmara data set shows that gas emissions are relatively more abundant around fault zones in a swath of 900 to $2 \mathrm{~km}$ half-width and this can be considered as a general indication of a higher permeability around faults. Fault permeability is generally ascribed to the presence of a fracture damage zone (e.g.: Caine et al., 1996; Faulkner et al., 2010). For crustal faults, the width of the damage zone scales with displacement so that the maximum width of the damage zone is of the same order as the total displacement, but this relationship saturates for displacements of more than about $2 \mathrm{~km}$ and the total width of the damage zone generally remains less than $1 \mathrm{~km}$ wide for larger displacements (Faulkner and Mitchell, 2011; Savage and Brodsky, 2011). Offset of 


\section{ACCEPTED MANUSCRIPT}

Cretaceous structures across the Northern Branch of the North Anatolian Fault has been claimed to be $52 \mathrm{~km} \pm 1 \mathrm{~km}$ east of the Sea of Marmara (Akbayram et al., 2016b) but part of this offset should have occurred in a post-collisional context, before the initiation of the North Anatolian Fault system during the Late Miocene (Akbayram et al., 2016a; Şengör, 1979). Several fault branches in the Marmara area have been localizing strain, and evolving, since the Pliocene (Le Pichon et al., 2014, 2015; Şengör et al., 2014) and most segments of the Main Marmara Fault (MMF) are probably younger than 2-2.5 Ma (Grall et al., 2012; Le Pichon et al., 2015) and, hence, cumulative displacement at the seafloor is smaller. However, displacement on the MMF may be at least $7 \mathrm{~km}$ (Grall et al., 2013) and any displacement larger than $2 \mathrm{~km}$ is expected to be associated with a fracture damage zone width of several hundred to a maximum of $1 \mathrm{~km}$ width.

The swath of acoustic anomalies and seafloor deformation zones associated with major faults thus appears generally wider than the fracture damage zone width observed at crustal level for a mature fault zone. A widely accepted geological explanation would be to consider that the seafloor free surface promotes the development of flower structures wherever geometrical asperities cause compressional or extensional stress (e.g. Harding, 1985) thus causing a broadening toward the seafloor of the deformation zone. Numerical models incorporating damage rheology also well account for the development of flower structures (Finzi et al., 2009). However, the question of its scale remains. In analog models of transform faults under pure strike-slip the width of the principal shear zone (in this case dominated by early en-echelon Riedel shears and later P-shears) represent about $1 / 2$ of the thickness of the layer of granular material used to represent the brittle crust and it broadens (up to a factor of 2 or 3 ) and becomes more complex when a regional component of transtension is introduced (Smit et al., 2010; Wu et al., 2009). The deformation zone also broadens at compressional and extensional stepovers (McClay and Bonora, 2001; Wu et al., 2009) but the presence of a ductile layer does not necessarily result in further broadening of the deformation zone (Smit et al., 2008). Moreover, numerical models incorporating damage rheology with parameters representative of crustal behavior predict flower structures about 10 $\mathrm{km}$ wide and extending to more than $5 \mathrm{~km}$ depth (Finzi et al. 2009). In the Sea of Marmara, flower structures have been described at crustal scale, involving tilted blocks, in the Eastern Sea of Marmara (Becel et al., 2010), and at the basin scale (Rangin et al., 2004). For instance, the transpressional active fault system affecting the Western High (Imren et al., 2001) and the transtensional system determining the present-day subsidence of the central basin (Grall et al., 2012) could be interpreted as flower structures that formed within the sedimentary cover. The 


\section{ACCEPTED MANUSCRIPT}

sedimentary cover is here 5 to $7 \mathrm{~km}$ thick, comprising syn-kinematic basin fill as well as, probably, Eocene-Oligocene sediments (Bayrakci et al, 2013; Kende et al., 2017). The deformation zones we observed at the seafloor around the MMF, and which appear to influence the distribution of fluid emissions, are typically narrower.

The deformation processes occurring around faults at crustal level may, however, differ from within the sediment fill of a rapidly subsiding basin and, hypothetically, the width of the seafloor deformation zones may be controlled by the thickness of the layer of highporosity sediment (range 70-35\%) undergoing mechanical compaction. Assuming damage rheology could also be applied to this layer, it would probably require taking into account a gradient in elastic moduli as well as different damage and healing parameters than for crustal scale models. Moreover, this layer has a distinct rheology, which may be described with soil mechanics models coupling stress state, porosity variations, and strain. The mechanical transition with depth occurs in the 1000-to-3000 $\mathrm{m}$ range in fine-grained siliciclastic sediments but is progressive and will depend on the porosity gradient in the sediment and on its stress history (Karig and Ask, 2003; Pouya et al., 1998). In this layer, rupture will occur for relatively higher strains than for consolidated rocks, and in models of continuous damage zone growth driven by asperity interaction, this could result in later development of secondary faults and continued linear damage zone growth proportional to displacement (beyond the $\approx 150 \mathrm{~m}$ scale inferred to be the threshold; Savage et al., 2011). In this layer, shear strain will also promote compaction and fluid expulsion and cause strain hardening, making this layer less strain localizing than rocks found at deeper levels, and this will also favor a broadening toward the seafloor of the fault shear zone. Such processes have also been invoked to explain the formation of mélanges in subduction zones (e.g.: Moore and Byrne, 1987). Coexistence of brittle fracturing and porosity loss in fault zones in fine grained sediments is commonly observed and (within the framework of soil mechanics) could result from strain applied successively on loading and unloading stress paths and/or fluid pressure cycling (e.g.: Bourlange et al., 2003; Conin et al., 2014). Bifurcation theory applied to strain localization also opens the possibility that a dilatant (hence more permeable) structure could form in a compacting material, depending on rheology and stress conditions (Bezuelle et al., 2001). These various processes can help explain how faults remain conduits for fluids in compacting fine-grained sediments, but it may be hypothesized that the efficiency of fluid channeling in fault damage zones decreases toward the seafloor. However, fracturing can still occur at very shallow depths. Joint sets and tension gashes are observed even in high porosity marine sediments and these often control the geometry and orientation of elongated zones of seepage 


\section{ACCEPTED MANUSCRIPT}

(e.g. Henry et al., 2002). Moreover, authigenic carbonate crusts forming at fluid emission sites favor crack development at the seafloor (Kobayashi, 2002). In the following we examine evidence from the Sea of Marmara that tensile cracks are providing pathways to gas in the last few tens of meters below the seafloor, and that those are not always associated with welldeveloped carbonate crusts.

\subsection{Gas migration pathways in shallow sediments}

Gas occurrence at a shallow depth in the Sea of Marmara sediment is widespread. Consequently, the presence of gas emissions within a deformation zone is not a demonstration that fluids migrate along the deeper part of the fault zone. Geochemical evidence may be considered more demonstrative and it shows that the expulsion of deep originated fluids tends to be focused at specific locations (fault intersections, anticline top, mud diapir or conduit) (Burnard et al., 2012; Ruffine et al., 2017; Tryon et al., 2010). However, there is no systematic relationship between gas composition and proximity to fault zones. For instance, thermogenic methane dominates fluid emissions over the top of the Central High and within the MMF deformation zone in the Western High (Bourry et al., 2008; Çağatay et al., 2017; Ruffine et al., 2017) but we showed that the distributions of seepages have different characteristics at both locations (broad leakage zone over an anticline vs. $2 \mathrm{~km}$ wide swath along the main fault). Close examination of the relationship between faults and gas emissions within seafloor deformation zones also shows that even at the 10-100 m scale of AUV maps and submersible observations (Figure 7 and Grall et al., this issue), many acoustic anomalies are not located on the outcrops of small faults. On the structural highs as well as in the peripheral parts of basins, gas present in the lacustrine sediments influences acoustic reflectivity and backscatter and disturbs the imaging of sedimentary layering with chirp sounder profiles, even in zones far away from the main faults (Zitter et al., 2012). Thin layers of sand tend to collect gas at high points resulting in high reflectivity patches in high resolution seismic profiles (e.g. Thomas et al., 2012). However, capillary effects limit upward migration of gas from these local accumulations, and, in order to reach the seafloor, the gas must traverse fine-grained sediments through fractures, a process that depends on local stress state and gas capillary pressure (e.g. Henry et al., 1999). The gas habits and migration processes in shallow sediments are further supported by observations on cores. Lacustrine sediments in the Sea of Marmara usually contain monosulfide accumulations, that form as a result of sulfate reduction and methane oxidation within the sediment, which typically occurs in the Sea of Marmara at depths ranging from the near seafloor to a maximum of $10 \mathrm{~m}$ depth 
(Ruffine et al., 2017; Tryon et al., 2010). Monosulfides may be found below as patches, within silty or sandy laminae, within ash layers, but also frequently in cracks. The larger accumulations cause magnetic susceptibility anomalies in the core logs (Figure 8), as most monosulfides (like Pyrrhotite) are antiferromagnetic or ferromagnetic while pure $\mathrm{FeS}$ (Troilite) and $\mathrm{FeS}_{2}$ (Pyrite) are paramagnetic. Those monosulfides are sometime associated with calcite. Monosulfides do not survive oxidation when the core is exposed to air but can be observed immediately after the core is opened. The core shown (Core MRS-CS22) is located on the Western High but is not closely associated with a fault outcrop or currently active seepage. Gas was probably no longer present in the cracks and sedimentary layers at the time of coring, as gas expansion would have damaged the core. However, the presence of monosulfides, or of their oxidation products, suggests laminae and cracks have contained methane. A large crack containing monosulfides has been observed at about $8 \mathrm{~m}$ below core surface, and likely provided a pathway for methane gas ascending toward the sulfate-methane reaction zone (Figure 8). The accumulation of dark sulfidic material around the crack upper tip is an indication that gas once contained in this crack diffused into the sediment to react with pore water sulfate. In the core section immediately below, small vertical cracks 1 to $3 \mathrm{~cm}$ in diameter with a brown iron hydroxide lining are found (Figure 9). These cracks have a preferred orientation within the core, which is presumably controlled by the orientation of the minimum stress and could constitute a pathway for fluid migration if they form a connected network. In the section shown (Figure 9), fractures are probably connected as, after sampling, oxygen made its way to the center of the core along the fractures while sulfide patches in the mud remained in their reduced state. It follows from these observations that the migration of gas in the last tens of meters of sediment will depend on the growth and coalescence of gas bearing cracks and will thus be sensitive to variations of gas pressure, stress and strain rate. The passing of seismic waves, stress variations before and after an earthquake as well as processes acting on a longer time scale such as folding and slope instability, or shallow distributed strain resulting from slip occurring at depths along a fault (Figure 10) may all contribute to crack growth and coalescence, and to increase the permeability of shallow sediment to gas.

\subsection{Regional variability of seep distribution and fault seismic and aseismic slip}

Seafloor deformation zones around the MMF and its branches are the main loci of gas emission through the seafloor on the Western High, and are also important ones in the basins, but their role do not appear as prominent on the Central High. In the Sea of Marmara deep 


\section{ACCEPTED MANUSCRIPT}

basins, buoyancy forces and sediment layering dips drive gas away from the depocenters toward the edges (Grall et al., this issue) resulting in focused fluid expulsion along these edges, even where no major active fault is mapped (e.g. N Tekirdag, and SE Kumburgaz). The difference observed between Central High and Western High requires another explanation. A longer time lapse since the last earthquake was proposed as a possible explanation (Geli et al., 2008) but recent studies also suggest the Main Marmara Fault has a deep creep component on the Western High, but not on the Central High (Bohnoff et al., 2017, 2013; Sakic et al., 2016; Schmittbuhl et al., 2016a and b; Yamamoto et al., 2016). Land GPS data indicate that the central part of the Main Marmara fault is not fully locked (Ergintav et al., 2014; Klein et al., 2017) but do not have today the resolution needed for an accurate determination of the distribution of interseismic loading rates vs aseisimic slip rates on the offshore fault (Klein et al., 2017). The Western High and the Central Basin area have a higher level of background seismicity that the adjacent Ganos segment on land and Istanbul-Silivri segment across the Central High, which may be an indication in favor of a component of deep creep (Schmittbuhl et al., 2016a). Observation of repeating small earthquakes bring further evidence in favor of creeping fault patches beneath the Western High and the Central Basin (Bohnhoff et al., 2017; Schmittbuhl et al., 2016b). These seismological studies do not constrain well the location (depth) and size of these patches but evaluate the fraction of the long-term fault slip rate currently accommodated by aseismic creep at about $25 \%$ for the Western High patch (Bohnhoff et al., 2017) and between $75 \%$ and 100\% for the Central Basin patch (Bohnhoff et al., 2017; Schmittbuhl et al., 2016b). Furthermore, preliminary results from an acoustic ranging experiment performed on the MMF on the Western High indicated aseismic creep rate at the seafloor of $9-16 \mathrm{~mm} / \mathrm{yr}$ from 18 months of data (Yamamoto et al., 2016). On the other hand, there is no indication than the MMF is creeping in the Central High and Kumburgaz Basin: microseismicity is very low and a similar acoustic ranging experiment set across the main fault trace could not detect creep (Sakic et al., 2016). The latest major earthquake on the Central High presumably occurred in 1766 , with magnitude $\mathrm{Ms} \approx 7.1$ (Ambraseis, 2002; Parsons et al., 2004; Pondard et al., 2007), which may have left enough time for pathways within the fault deformation zone to self-seal (Hovland, 2002).

One should not exclude that ground shaking caused by moderate seismicity (involving magnitude 4 to 5 earthquakes) could also contribute to keep the upper layers of sediment more permeable in the Western High area than on the Central High. However, the radius of the zone where an earthquake is empirically found to influence fluid emission by various mechanisms (e.g. liquefaction, permeability change) is several km for magnitude $4,10-20 \mathrm{~km}$ 


\section{ACCEPTED MANUSCRIPT}

for magnitude 5 (Manga et al., 2009; Wang, 2007; Wang and Manga, 2010). This could result in enhanced fluid emission on the Western High as a whole but would not explain the focusing of fluid emissions within the deformation zone. Moreover, acoustic surveys in 2009 (Marmesonet cruise with R.V. Le Surôtt) and 2014 (Marsite cruise with R.V. Pourquoi pas ?) did not show obvious variations in the pattern of gas emission between one year before and 3 years after a Mw 5.1 earthquake, which occurred in the Western High area on July 25, 2011. After the 1999 Kocali-Izmit earthquake, an increase of gas emission fluxes was observed (Alpar et al., 1999; Kuscu et al., 2005), but the evolution with time of the post-earthquake gas emission fluxes was not closely monitored, leaving little information on the time needed for the perturbed gas emission system to recover. This leaves open the possibility that gas fluxes are influenced not only by earthquakes, but also, as we suggest, by on-going aseismic deformation of the sediments.

The conceptual model we propose distinguishes gas migration pathways controlled by sedimentary structure and gas migration along faults (Figure 11). Updip migration along permeable strata will result in gas migration toward the edges of the basins and its accumulation in anticlines and at sedimentary discontinuities (sediment-basement contact and intra-sediment onlaps). Gas is eventually expelled along anticlines through extensional structures or along basin edges. This pattern will be observed if faults do not have high permeability, which may be the case during the interseismic period if faults are locked. It can be suggested that this is the current state in the Central High zone. After an earthquake, permeability increase in the ruptured fault enables focused fluid migration through the fault zone and a transient redistribution of gas emission sites at the seafloor. If fault creep also enhances permeability, permanent fluid expulsion through creeping fault zones could occur, following a similar pattern as for post-seismic fluid flow. It can be suggested that this is the case for the Western High zone.

\section{Conclusion}

Faults clearly influence the distribution of gas emission through the seafloor in the Sea of Marmara and a majority of gas emissions in the Sea of Marmara are located within less than $750 \mathrm{~m}$ from an active fault. However, about $20 \%$ of the gas emissions are too far from any active faults to be influenced by fluid migration in fault zones. On the other hand, highresolution seafloor mapping shows a seafloor deformation zone around the main active fault segments (Grall et al., this issue). The half width of the seafloor deformation zone is also about $1 \mathrm{~km}$, which makes it broader than the typical damage zone of a crustal fault, but 


\section{ACCEPTED MANUSCRIPT}

narrower than crustal or basin scale flower structures. We suspect this deformation zone results from the broadening within high porosity fined-grained sediments in the first 1 to $3 \mathrm{~km}$ below the seafloor of the damage zone associated with crustal faults. We also show that gas migrates through shallow sediments in fracture networks. In the Sea of Marmara, these processes apparently result in a higher permeability of sediment to gas in a $\approx 2 \mathrm{~km}$ swath around major faults. The general applicability of these results to other transform faults or to faults in other tectonic settings remains to be assessed. It also remains unclear how the distance distribution would be changed if more detailed maps including smaller scale faults would be used. Assuming small faults are not evenly distributed but mostly located within the seafloor deformation zone of larger faults, the shape of the distance distribution should be similar for distances larger than the half-width of the deformation zones but should differ for shorter distances.

In the Sea of Marmara fluid emissions tend to be more focused around faults in the basins and on the Western High where the half-width of the gas emission swaths is less than 1 $\mathrm{km}$, than on the Central High, where it is about $2 \mathrm{~km}$. Recent studies in seismology and geodesy suggest that the Western High segment of the Main Marmara fault is creeping at about $1 / 2$ of plate velocity, possibly even more (this causing important microseismicity), while the Central High segment is apparently locked. It can be proposed that steady creep is maintaining a higher permeability in the MMF seafloor deformation zone across the Western High, while the Central High MMF seafloor deformation zone has self-sealed since the last major earthquake that affected this segment, presumably in 1766. However, interpreting the spatial distribution of fluid emissions in term of fault seismic or aseismic behavior remains generally uncertain. Monitoring of fluid emissions is sometime proposed as a possible way to help anticipate earthquakes. Monitoring of gas emissions after earthquakes, including moderate ones, and a rapid response approach, may be easier to implement at first and will yield useful information on the coupling between fluid migration and strain in fault zones and on characteristic times involved in the healing of fractures and faults.

\section{Acknowledgements}

The fault database used in this study was funded by MARSITE FP7 EU project (Grant Agreement Number: 308417, Deliverable D7.2). INSU supported CEREGE participation to MARSITECRUISE on board R/V Pourquoi Pas ? and the GENAVIR shipboard crew and IFREMER support team are here thanked for recovering and handling high quality sediment cores. Funding by COST action FLOWS (ES1301) of short term scientific missions between 


\section{ACCEPTED MANUSCRIPT}

ITÜ and CEREGE has also been of considerable help. ANR-16-CE03-0010-02 MAREGAMI

funded the final stages of this work.

\section{References}

Akbayram, K., Şengör, A.M.C., Özcan, E., 2016b. The evolution of the Intra-Pontide suture : Implications of the discovery of late Cretaceous - early Tertiary mélanges, in: Sorkhabi, R. (Ed.), Tectonic Evolution, Collision, and Seismicity of Southwest Asia: In Honor of Manuel Berberian's Forty-Five Years of Research Contributions: Geological Society of America Special Paper 525. doi:10.1130/2016.2525(18)

Akbayram, K., Sorlien, C.C., Okay, A.I., 2016a. Evidence for a minimum $52 \pm 1 \mathrm{~km}$ of total offset along the northern branch of the North Anatolian Fault in northwest Turkey. Tectonophysics 668-669, 35-41. doi:10.1016/j.tecto.2015.11.026

Ambraseys, N., 2002. The seismic activity of the Marmara Sea region over the last 2000 years. Bull. Seismol. Soc. Am. 92, 1-18. doi:10.1785/0120000843

Alpar, B., 1999. Underwater Signatures of the Kocaeli Earthquake ( August 17th 1999 ). Turkish J. Mar. Sci. 5, 111-130.

Armijo, R., Meyer, B., Navarro, S., King, G., Barka, A., 2002. Asymmetric slip partitioning in the sea of Marmara pull-apart: A clue to propagation processes of the North Anatolian Fault? Terra Nov. 14, 80-86. doi:10.1046/j.1365-3121.2002.00397.x

Augustin, J.-M., 2011. Developing and Deploying Sonar and Echosounder Data Analysis Software, Matlab Newsletters,

http://www.mathworks.fr/company/newsletters/articles/developing-and-deploying-sonarand-echosounder-data-analysis-software.html

Baddeley, A., 2007. Spatial Point Processes and their Applications, in: Weil, W. (Ed.), Stochastic Geometry. Springer Berlin Heidelberg, Berlin, Heidelberg, pp. 1-75. doi:10.1007/978-3-540-38175-4_1

Barnes, P.M., Lamarche, G., Bialas, J., Henrys, S., Pecher, I., Netzeband, G.L., Greinert, J., Mountjoy, J.J., Pedley, K., Crutchley, G., 2010. Tectonic and geological framework for gas hydrates and cold seeps on the Hikurangi subduction margin, New Zealand. Mar. Geol. 272, 26-48. doi:10.1016/j.margeo.2009.03.012

Bayrakci, G., Laigle, M., Bécel, a., Hirn, a., Taymaz, T., Yolsal-Çevikbilen, S., 2013. 3-D sediment-basement tomography of the Northern Marmara trough by a dense OBS network at the nodes of a grid of controlled source profiles along the North Anatolian fault. Geophys. J. Int. 194, 1335-1357. doi:10.1093/gji/ggt211

Bécel, A., Laigle, M., de Voogd, B., Hirn, A., Taymaz, T., Yolsal-Cevikbilen, S., Shimamura, H., 2010. North Marmara Trough architecture of basin infill, basement and faults, from PSDM reflection and OBS refraction seismics. Tectonophysics 490, 1-14. doi:10.1016/j.tecto.2010.04.004

Bésuelle, P., 2001. Compacting and dilating shear bands in porous rock: Theoretical and experimental conditions. Journal of Geophysical Research: Solid Earth, 106(B7), 1343513442. https://doi.org/10.1029/2001JB900011

Bohnhoff, M., Wollin, C., Domigall, D., Küperkoch, L., Martínez-Garzón, P., Kwiatek, G., Dresen, G., Malin, P.E., 2017. Repeating Marmara Sea earthquakes: indication for fault creep. Geophys. J. Int. 210, 332-339. doi:10.1093/gji/ggx169

Bohrmann, G., Heeschen, K., Jung, C., Weinrebe, W., Baranov, B., Cailleau, B., Heath, R., Hühnerbach, V., Hort, M., Masson, D., Trummer, I., 2002. Widespread fluid expulsion along the seafloor of the Costa Rica convergent margin. Terra Nov. 14, 69-79. doi:10.1046/j.1365-3121.2002.00400.x 
Bourlange, S., Henry, P., Moore, J. C., Mikada, H., \& Klaus, A., 2003. Fracture porosity in the décollement zone of Nankai accretionary wedge using Logging While Drilling resistivity data. Earth and Planetary Science Letters, 209(1-2), 103-112, DOI:10.1016/S0012-821X(03)00082-7

Burnard, P., Bourlange, S., Henry, P., Geli, L., Tryon, M.D., Natal'in, B., Sengör, A.M.C., Özeren, M.S., Çagatay, M.N., 2012. Constraints on fluid origins and migration velocities along the Marmara Main Fault (Sea of Marmara, Turkey) using helium isotopes. Earth Planet. Sci. Lett. 341-344, 68-78. doi:10.1016/j.eps1.2012.05.042

Çağatay, M. N., Yıldız, G., Bayon, G., Ruffine, L., \& Henry, P. (2017). Seafloor authigenic carbonate crusts along the submerged part of the North Anatolian Fault in the Sea of Marmara: Mineralogy, geochemistry, textures and genesis. Deep Sea Research Part II: Topical Studies in Oceanography. https://doi.org/10.1016/j.dsr2.2017.09.003

Caine, J.S., Evans, J.P., Forster, C.B., 1996. Fault zone architechture and permeability structure. Geology 24, 1025-1028.

Carton, H., Singh, S.C., Hirn, A., Bazin, S., de Voogd, B., Vigner, A., Ricolleau, A., Cetin, S., Oçakoğ lu, N., Karakoç, F., Sevilgen, V., 2007. Seismic imaging of the threedimensional architecture of the Çınarcık Basin along the North Anatolian Fault. J. Geophys. Res. Solid Earth 112, 1-17. doi:10.1029/2006JB004548

Chamot-Rooke, N., Rabaute, A., Kreemer, C., 2005. Western Mediterranean Ridge mud belt correlates with active shear strain at the prism-backstop geological contact. Geology 33, 861. doi:10.1130/G21469.1

Chester, F. M., Logan, J. M. (1986). Implications for mechanical properties of brittle faults from observations of the Punchbowl fault zone, California. Pure and Applied Geophysics PAGEOPH, 124(1-2), 79-106. https://doi.org/10.1007/BF00875720

Conin, M., Bourlange, S., Henry, P., Boiselet, A., \& Gaillot, P., 2014. Distribution of resistive and conductive structures in Nankai accretionary wedge reveals contrasting stress paths. Tectonophysics, 611, 181-191, DOI:10.1016/j.tecto.2013.11.025

Demirbağ, E., Rangin, C., Le Pichon, X., Şengör, A.M.C., 2003. Investigation of the tectonics of the Main Marmara Fault by means of deep-towed seismic data. Tectonophysics 361, 1-19. doi:10.1016/S0040-1951(02)00535-8

Dupré, S., Scalabrin, C., Grall, C., Augustin, J.-M., Henry, P., Şengör, A.M.C., Görür, N., Çağatay, M.N., Géli, L., 2015. Tectonic and sedimentary controls on widespread gas emissions in the Sea of Marmara: Results from systematic, shipborne multibeam echo sounder water column imaging. J. Geophys. Res. Solid Earth 120, 2891-2912. doi:10.1002/2014JB011617

Dupré, S., L. Berger, N. Le Bouffant, C. Scalabrin, and J.-F. Bourillet, 2014. Fluid emissions at the Aquitaine Shelf (Bay of Biscay, France): A biogenic origin or the expression of hydrocarbon leakage?, Continental Shelf Research, 88, 24-33.

Dupré, S., J. Woodside, I. Klaucke, J. Mascle, and J.-P. Foucher, 2010. Widespread active seepage activity on the Nile Deep Sea Fan (offshore Egypt) revealed by high-definition geophysical imagery, Marine Geology, 275(1-4), 1-19.

Faulkner, D.R., Jackson, C.A.L., Lunn, R..J., Schlische, R.W., Shipton, Z.K., Wibberley, C.A.J., Withjack, M.O., 2010. A review of recent developments concerning the structure, mechanics and fluid flow properties of fault zones. J. Struct. Geol. 32, 1557-1575. doi:10.1016/j.jsg.2010.06.009

Faulkner, D.R., Mitchell, T.M., Jensen, E., Cembrano, J., 2011. Scaling of fault damage zones with displacement and the implications for fault growth processes. J. Geophys. Res. Solid Earth 116, 1-11. doi:10.1029/2010JB007788

Finzi, Y., Hearn, E.H., Ben-Zion, Y., Lyakhovsky, V., 2009. Structural Properties and Deformation Patterns of Evolving Strike-slip Faults: Numerical Simulations 


\section{ACCEPTED MANUSCRIPT}

Incorporating Damage Rheology. Pure Appl. Geophys. 166, 1537-1573. doi:10.1007/s00024-009-0522-1

Gay, A., Lopez, M., Berndt, C., Séranne, M., 2007. Geological controls on focused fluid flow associated with seafloor seeps in the Lower Congo Basin. Mar. Geol. 244, 68-92. doi:10.1016/j.margeo.2007.06.003

Géli, L., Henry, P., Zitter, T., Dupré, S., Tryon, M., Çağ atay, M.N., de Lépinay, B.M., Le Pichon, X., Şengör, a. M.C., Görür, N., Natalin, B., Uçarkuş, G., Özeren, S., Volker, D., Gasperini, L., Burnard, P., Bourlange, S., the Marnaut Scientific Party, 2008. Gas emissions and active tectonics within the submerged section of the North Anatolian Fault zone in the Sea of Marmara. Earth Planet. Sci. Lett. 274, 34-39. doi:10.1016/j.epsl.2008.06.047

Geli, L., Henry, P., Cagatay, M.N., 2009. Marmesonet Leg 1 Cruise Report. http://www.ifremer.fr/sismer/

Grall, C., 2013. La Faille Nord Anatolienne dans sa portion immergée en mer de Marmara : évolution du réseau de failles et migration de fluides. PhD Thesis, Aix-Marseille Université.

Grall, C., Henry, P., Tezcan, D., Mercier de Lepinay, B., Becel, A., Geli, L., Rudkiewicz, J.L., Zitter, T., Harmegnies, F., 2012. Heat flow in the Sea of Marmara Central Basin: Possible implications for the tectonic evolution of the North Anatolian fault. Geology 40, 3-6. doi:10.1130/G32192.1

Grall, C., Henry, P., Thomas, Y., Westbrook, G.K., Çağ atay, M.N., Marsset, B., Saritas, H., Çifçi, G., Géli, L., 2013. Slip rate estimation along the western segment of the main marmara fault over the last 405-490 ka by correlating mass transport deposits. Tectonics 32, 1587-1601. doi:10.1002/2012TC003255

Grall, C., Henry, P., Zitter, T.A.C., Dupré, S., Geli, L., Scalabrin, C., Sengör, A.M.C., Cagatay, M.N., Cifci, G., (2018) Gas updip migration in an active tectonic basin: role of fault damaging at shallow depth and sedimentation, the example of the sea of Marmara. Deep Sea Res. Part I Oceanogr. Res. Pap. This issue.

Greinert, J., Y. Artemov, V. Egorov, M. De Batist, and D. McGinnis, 2006. 1300-m-high rising bubbles from mud volcanoes at $2080 \mathrm{~m}$ in the Black Sea: Hydroacoustic characteristics and temporal variability, Earth and Planetary Science Letters, 244(1-2), 115.

Harding, T.P., 1985. Seismic Characteristics and Identification of Negative Flower Structures, Positive Flower Structures, and Positive Structural Inversion. Am. Assoc. Pet. Geol. Bull. 69, 582-600.

Henry, P., Lallemant, S.J., Le Pichon, X., Lallemand, S.E., 1989. Fluid venting along Japanese trenches: tectonic context and thermal modeling. Tectonophysics 160, 277291. doi:10.1016/0040-1951(89)90396-X

Henry, P., Lallemant, S., Nakamura, K., Tsunogai, U., Mazzotti, S., Kobayashi, K., 2002. Surface expression of fluid venting at the toe of the Nankai wedge and implications for flow paths. Mar. Geol. 187, 119-143.

Henry, P., Şengör, A.M.C., Çağatay, M.N., et al., 2007. Marnaut 2007 Dive Reports. http://www.ifremer.fr/sismer/program/csus/htql/campagne.htql?CRNO=7010070

Henry, P., Thomas, M., \& Clennell, M.B., 1999. Formation of natural gas hydrates in marine sediments: 2 . Thermodynamic calculations of stability conditions in porous sediments. Journal of Geophysical Research: Solid Earth, 104(B10), 23005-23022, doi:10.1029/1999JB900167

Hovland, M., 2002. On the self-sealing nature of marine seeps. Cont. Shelf Res. 22, 23872394. doi:10.1016/S0278-4343(02)00063-8 
Imren, C., Le Pichon, X., Rangin, C., Demirbag, E., Ecevitoglu, B., Görür, N., 2001. The North Anatolian fault within the Sea of Marmara: a new evaluation based on multichannel seismic and multibeam data. Earth Planet. Sci. Lett. 186, 143-158.

Karig, D.E., Ask, M.V.S., 2003. Geological perspectives on consolidation of clay-rich marine sediments. J. Geophys. Res. Solid Earth 108, 1-14. doi:10.1029/2001JB000652

Kende, J., Henry, P., Bayrakci, G., Özeren, M.S., Grall, C., 2017. Moho depth and crustal thinning in the Marmara Sea region from gravity data inversion. J. Geophys. Res. Solid Earth 122, 1381-1401. doi:10.1002/2015JB012735

Kim, Y.-S., Peacock, D. C. P., Sanderson, D. J. (2004). Fault damage zones. Journal of Structural Geology, 26(3), 503-517. https://doi.org/10.1016/j.jsg.2003.08.002

Klaucke, I., H. Sahling, W. Weinrebe, V. Blinova, D. Burk, N. Lursmanashvili, and G. Bohrmann, 2006. Acoustic investigation of cold seeps offshore Georgia, eastern Black Sea, Marine Geology, 231(1-4), 51-67.

Klein, E., Duputel, Z., Masson, F., Yavasoglu, H., \& Agram, P. (2017). Aseismic slip and seismogenic coupling in the Marmara Sea: What can we learn from onland geodesy? Geophysical Research Letters, 44(7), 3100-3108. https://doi.org/10.1002/2017GL072777

Kobayashi, K., 2002. Tectonic significance of the cold seepage zones in the eastern Nankai accretionary wedge - An outcome of the 15 years' KAIKO projects. Mar. Geol. 187, 330. doi:10.1016/S0025-3227(02)00242-6

Kurt, H., Sorlien, C. C., Seeber, L., Steckler, M. S., Shillington, D. J., Cifci, G., ... Carton, H. (2013). Steady late quaternary slip rate on the Cinarcik section of the North Anatolian fault near Istanbul, Turkey. Geophysical Research Letters, 40(17), 4555-4559. https://doi.org/10.1002/grl.50882

Kuşçu, I., Okamura, M., Matsuoka, H., Gökaşan, E., Awata, Y., Tur, H., Şimşek, M., Keçer, M., 2005. Seafloor gas seeps and sediment failures triggered by the August 17, 1999 earthquake in the Eastern part of the Gulf of İzmit, Sea of Marmara, NW Turkey. Mar. Geol. 215, 193-214. doi:10.1016/j.margeo.2004.12.002

Lallemand, S.E., Glaçon, G., Lauriat-Rage, A., Fiala-Médioni, A., Cadet, J.-P., Beck, C., Sibuet, M., Iiyama, J.T., Sakai, H., Taira, A., 1992. Seafloor manifestations of fluid seepage at the top of a 2000-metre-deep ridge in the eastern Nankai accretionary wedge: Long-lived venting and tectonic implications. Earth Planet. Sci. Lett. 109, 333-346. doi:10.1016/0012-821X(92)90096-E

Le Pichon, X., İmren, C., Rangin, C., Şengör, A. M.C., Siyako, M., 2014. The South Marmara Fault. Int. J. Earth Sci. 103, 219-231. doi:10.1007/s00531-013-0950-0

Le Pichon, X., Kobayashi, K., Kaiko-Nankai Scientific Crew, 1992. Fluid venting activity within the eastern Nankai trough accretionary wedge: A summary of the 1989 KaikoNankai results. Earth Planet. Sci. Lett. 109, 303-318. doi:10.1016/0012-821X(92)90094$\mathrm{C}$

Le Pichon, X., Şengor, A.M.C., Demirbağ, E., Rangin, C., Imren, C., Armijo, R., Görür, N., Cağatay, N., Mercier de Lepinay, B., Meyer, B., Saatçilar, R., Tok, B., 2001. The active Main Marmara Fault. Earth Planet. Sci. Lett. 192, 595-616. doi:10.1016/S0012821X(01)00449-6

Le Pichon, X., Şengör, C., Kende, J., İmren, C., Henry, P., Grall, C., Karabulut, H., 2015. Propagation of a strike slip plate boundary within an extensional environment: the westward propagation of the North Anatolian Fault. Can. J. Earth Sci. cjes-2015-0129. doi:10.1139/cjes-2015-0129

Loncke, L., Mascle, J., Fanil Scientific Parties, 2004. Mud volcanoes, gas chimneys, pockmarks and mounds in the Nile deep-sea fan (Eastern Mediterranean): geophysical evidences. Mar. Pet. Geol. 21, 669-689. doi:10.1016/j.marpetgeo.2004.02.004 
Manga, M., Brumm, M., Rudolph, M.L., 2009. Earthquake triggering of mud volcanoes. Mar. Pet. Geol. 26, 1785-1798. doi:10.1016/j.marpetgeo.2009.01.019

McClay, K., Bonora, M., 2001. Analog models of restraining stepovers in strike-slip fault systems. Am. Assoc. Pet. Geol. Bull. 85, 233-260. doi:10.1306/8626C7AD-173B-11D7$8645000102 \mathrm{C} 1865 \mathrm{D}$

Medialdea, T., Somoza, L., Pinheiro, L.M., Fernández-Puga, M.C., Vázquez, J.T., León, R., Ivanov, M.K., Magalhaes, V., Díaz-del-Río, V., Vegas, R., 2009. Tectonics and mud volcano development in the Gulf of Cádiz. Mar. Geol. 261, 48-63. doi:10.1016/j.margeo.2008.10.007

Merewether, R., M. S. Olsson, and P. Lonsdale, 1985. Acoustically detected hydrocarbon plumes rising from 2-km depths in Guaymas Basin, Gulf of California, Journal of Geophysical Research: Solid Earth, 90(B4), 3075-3085.

Moore, J.C., Byrne, T., 1987. Thickening of fault zones: A mechanism of melange formation in accreting sediments. Geology 15, 1040. doi:10.1130/00917613(1987)15<1040:TOFZAM>2.0.CO;2

Moore, J.C., Orange, D., Kulm, L.D., 1990. Interrelationship of fluid venting and structural evolution: Alvin observations from the frontal accretionary prism, Oregon. J. Geophys. Res. 95, 8795. doi:10.1029/JB095iB06p08795

Orange, D.L., Yun, J., Maher, N., Barry, J., Greene, G., 2002. Tracking California seafloor seeps with bathymetry, backscatter and ROVs. Cont. Shelf Res. 22, 2273-2290. doi:10.1016/S0278-4343(02)00054-7

Pondard, N., Armijo, R., King, G.C.P., Meyer, B., Flerit, F., 2007. Fault interactions in the Sea of Marmara pull-apart (North Anatolian Fault): Earthquake clustering and propagating earthquake sequences. Geophys. J. Int. 171, 1185-1197. doi:10.1111/j.1365246X.2007.03580.X

Parke, J.R., White, R.S., McKenzie, D., Minshull, T.A., Bull, J.M., Kuşçu, I., Görür, N., Şengör, C., 2002. Interaction between faulting and sedimentation in the Sea of Marmara, western Turkey. J. Geophys. Res. Solid Earth 107, EPM 2-1-EPM 2-20. doi:10.1029/2001JB000450

Parke, J. R., Minshull, T. A., Anderson, G., White, R. S., McKenzie, D., Kuşcu, I., Şengör, C. (1999). Active faults in the Sea of Marmara, western Turkey, imaged by seismic reflection profiles. Terra Nova, 11(5), 223-227. https://doi.org/10.1046/j.13653121.1999.00248.x

Parsons, T., 2004. Recalculated probability of $M \geq 7$ earthquakes beneath the Sea of Marmara, Turkey. J. Geophys. Res. Solid Earth 109, 1-21. doi:10.1029/2003JB002667

Paull, C.K., Schlining, B., Ussler, W., Paduan, J.B., Caress, D., Greene, H.G., 2005. Distribution of chemosynthetic biological communities in Monterey Bay, California. Geology 33, 85. doi:10.1130/G20927.1

Pouya, A., Djeran-Maigre, I., Lamoureux-Var, V., Grunberger, D., 1998. Mechanical behaviour of fine-grained sediments: experimental compaction and three-dimensional constitutive model. Mar Pet Geol 15, 129-143.

Rangin, C., Le Pichon, X., Demirbag, E., Imren, C., 2004. Strain localization in the Sea of Marmara: Propagation of the North Anatolian Fault in a now inactive pull-apart. Tectonics 23, 1-18. doi:10.1029/2002TC001437

Ruffine, L., Donval, J.-P., Croguennec, C., Burnard, P., Lu, H., Germain, Y., ... Géli, L. (2017). Multiple gas reservoirs are responsible for the gas emissions along the Marmara fault network. Deep Sea Research Part II: Topical Studies in Oceanography, (xxxx). https://doi.org/10.1016/j.dsr2.2017.11.011

Sakic, P., Piété, H., Ballu, V., Royer, J.-Y., Kopp, H., Lange, D., Petersen, F., Özeren, M.S., Ergintav, S., Geli, L., Henry, P., Deschamps, A., 2016. No significant steady state 


\section{ACCEPTED MANUSCRIPT}

surface creep along the North Anatolian Fault offshore Istanbul: Results of 6 months of seafloor acoustic ranging. Geophys. Res. Lett. 43, 6817-6825. doi:10.1002/2016GL069600

Savage, H.M., Brodsky, E.E., 2011. Collateral damage: Evolution with displacement of fracture distribution and secondary fault strands in fault damage zones. J. Geophys. Res. Solid Earth 116. doi:10.1029/2010JB007665

Schmittbuhl, J., Karabulut, H., Lengliné, O., Bouchon, M., 2016a. Seismicity distribution and locking depth along the Main Marmara Fault, Turkey. Geochemistry, Geophys. Geosystems 17, 954-965. doi:10.1002/2015GC006120

Schmittbuhl, J., Karabulut, H., Lengliné, O., Bouchon, M., 2016b. Long-lasting seismic repeaters in the Central Basin of the Main Marmara Fault. Geophys. Res. Lett. 43, 95279534. doi:10.1002/2016GL070505

Seeber, L., Cormier, M. H., McHugh, C., Emre, O., Polonia, A., Sorlien, C. (2006). Rapid subsidence and sedimentation from oblique slip near a bend on the North Anatolian transform fault in the Marmara Sea, Turkey. Geology, 34, 933-936. https://doi.org/10.1130/G22520A.1

Sengör, A.M.C., 1979. The North Anatolian transform fault: its age, offset and tectonic significance. J. Geol. Soc. London. 136, 269-282. doi:10.1144/gsjgs.136.3.0269

Şengör, A.M.C., Grall, C., İmren, C., Le Pichon, X., Görür, N., Henry, P., Karabulut, H., Siyako, M., 2014. The geometry of the North Anatolian transform fault in the Sea of Marmara and its temporal evolution: implications for the development of intracontinental transform faults 1. Can. J. Earth Sci. 51, 222-242. doi:10.1139/cjes-2013-0160

Shillington, D.J., Seeber, L., Sorlien, C.C., Steckler, M.S., Kurt, H., Dondurur, D., Çifçi, G., Imren, C., Cormier, M.H., McHugh, C.M.G., Gürçay, S., Poyraz, D., Okay, S., Atgin, O., Diebold, J.B., 2012. Evidence for widespread creep on the flanks of the sea of Marmara transform basin from marine geophysical data. Geology 40, 439-442. doi:10.1130/G32652.1

Shipton, Z. K., \& Cowie, P. A. (2001). Damage zone and slip-surface evolution over $\mu \mathrm{m}$ to $\mathrm{km}$ scales in high-porosity Navajo sandstone, Utah. Journal of Structural Geology, 23(12), 1825-1844. https://doi.org/10.1016/S0191-8141(01)00035-9

Sibuet, M., Juniper, K.S., Pautot, G., 1988. Cold-seep benthic communities in the Japan subduction zones: Geological control of community development. J. Mar. Res. 46, 333348. doi:10.1357/002224088785113595

Smit, J., Brun, J.-P., Cloetingh, S., Ben-Avraham, Z., 2008. Pull-apart basin formation and development in narrow transform zones with application to the Dead Sea Basin. Tectonics 27, n/a-n/a. doi:10.1029/2007TC002119

Smit, J., Brun, J.-P., Cloetingh, S., Ben-Avraham, Z., 2010. The rift-like structure and asymmetry of the Dead Sea Fault. Earth Planet. Sci. Lett. 290, 74-82. doi:10.1016/j.eps1.2009.11.060

Sorlien, C.C., Akhun, S.D., Seeber, L., Steckler, M.S., Shillington, D.J., Kurt, H., Çifçi, G., Poyraz, D.T., Gürçay, S., Dondurur, D., İmren, C., Perinçek, E., Okay, S., Küçük, H.M., Diebold, J.B., 2012. Uniform basin growth over the last 500ka, North Anatolian Fault, Marmara Sea, Turkey. Tectonophysics 518-521, 1-16. doi:10.1016/j.tecto.2011.10.006

Sund, O., 1935. Echo sounding in fishery research, Nature, Letters to the editor, 135, 953.

Thomas, Y., Marsset, B., Westbrook, G.K., Grail, C., Géli, L., Henry, P., Çifçi, G., Rochat, A., Saritas, H., 2012. Contribution of high-resolution 3D seismic near-seafloor imaging to reservoir-scale studies: Application to the active North Anatolian Fault, Sea of Marmara. Near Surf. Geophys. 10, 291-301. doi:10.3997/1873-0604.2012019

Tryon, M.D., Henry, P., Çağ atay, M.N., Zitter, T. a C., Géli, L., Gasperini, L., Burnard, P., Bourlange, S., Grall, C., 2010. Pore fluid chemistry of the North Anatolian Fault zone in 
the Sea of Marmara: A diversity of sources and processes. Geochemistry, Geophys. Geosystems 11, 1-22. doi:10.1029/2010GC003177

Tryon, M.D., Henry, P., Hilton, D.R., 2012. Quantifying submarine fluid seep activity along the North Anatolian Fault Zone in the Sea of Marmara. Mar. Geol. 315-318, 15-28. doi:10.1016/j.margeo.2012.05.004

Wang, C.-Y., 2007. Liquefaction beyond the Near Field. Seismol. Res. Lett. 78, 512-517. doi:10.1785/gssrl.78.5.512

Wang, C., Manga, M., 2009. Earthquakes and Water, Lecture Notes in Earth Sciences. Springer Berlin Heidelberg, Berlin, Heidelberg. doi:10.1007/978-3-642-00810-8

Wu, J.E., McClay, K., Whitehouse, P., Dooley, T., 2009. 4D analogue modelling of transtensional pull-apart basins. Mar. Pet. Geol. 26, 1608-1623. doi:10.1016/j.marpetgeo.2008.06.007

Yamamoto, R., Kido, M., Ohta, Y., Takahashi, N., Yamamoto, Y., Kalafat, D., ... \& Yoshiyuki, K., 2016. Estimating slip deficit of the North Anatolian Fault beneath the Sea of Marmara, Turkey, using on- and off-shore geodetic data. In AGU Fall Meeting Abstracts, G51A-1061.

Zitter, T.A.C., Grall, C., Henry, P., Özeren, M.S., Çağ atay, M.N., Şengör, a. M.C., Gasperini, L., de Lépinay, B.M., Géli, L., 2012. Distribution, morphology and triggers of submarine mass wasting in the Sea of Marmara. Mar. Geol. 329-331, 58-74. doi:10.1016/j.margeo.2012.09.002

Zitter, T.A.C., Henry, P., Aloisi, G., Delaygue, G., Çagatay, M.N., Mercier de Lepinay, B., Al-Samir, M., Fornacciari, F., Tesmer, M., Pekdeger, A., Wallmann, K., Lericolais, G., 2008. Cold seeps along the main Marmara Fault in the Sea of Marmara (Turkey). Deep. Res. Part I Oceanogr. Res. Pap. 55, 552-570. doi:10.1016/j.dsr.2008.01.002 


\section{ACCEPTED MANUSCRIPT}

Figure 1: Bathymetric map of the Sea of Marmara, multi-beam survey tracks acquired during Marmesonet 2009 and water column acoustic anomalies interpreted as gas plumes (red dots) (Dupré et al., 2015). Tracks in the central part of the survey are spaced $800 \mathrm{~m}$ and the detection range of the gas plumes in the water column is $600 \pm 200 \mathrm{~m}$.

Figure 2: Simrad EM302 multi-beam echo sounder data acquired during Marmesonet 2009 cruise (R/V Le Suroît). The figure was prepared with Globe software (developed by Ifremer) and displays 3D bathymetry of the Sea of Marmara western high and an example of water column polar echogram. The polar echogram shows two plumes of gas bubbles emitted from the seafloor at $600 \mathrm{~m}$ water depth, from the top of a ridge located about $600 \mathrm{~m}$ south of the Main Marmara Fault. The noise on the external beams here limit the maximum range of gas plume detection to about $500 \mathrm{~m}$.

Figure 3: Tectonic map of the Sea of Marmara, based on a compilation by Şengör et al. (2014). Confirmed active fault traces are indicated in red, blind or inactive faults are indicated in dark grey. The Main Marmara Fault (MMF), indicated as a thick semi-transparent line, takes up $2 / 3$ to $3 / 4$ of the $24 \mathrm{~mm} / \mathrm{yr}$ right lateral plate motion between Anatolia and Eurasia (Le Pichon et al., 2001, 2015; Kurt et al., 2013; Grall et al., 2013). The last significant earthquake ruptures on the Ganos, Istanbul, Prince Islands and Izmit segment are indicated based on interpretations of historical records (Ambraseis, 2002; Parsons, 2004; Pondard et al., 2007). Slow slip (creep) is suspected on the segment extending from Tekirdag Basin to the Central Basin (Schmittbuhl et al., 2016a, 2016b; Yamamoto et al., 2016; Bohnhoff et al., 2017; Klein et al., 2017). Location of core MRS-CS22 (Figure 8 and 9) is indicated.

Figure 4: Distribution with respect to active faults of (A) acoustic anomalies indicative of gas emission sites; (B) random distribution generated with uniform probability within the zone covered by the multi-beam water column survey. Ship tracks are visible in this random uniform distribution where ship track spacing is wider than the nominal width of the acoustic survey swaths (taken equal to $1200 \mathrm{~m}$, see text). The Western High (WH) and Central High $(\mathrm{CH})$ zone boxes are shown.

Figure 5: Histograms of minimum distance between observed acoustic anomalies and faults (empty bars with black outline) and between uniformly distributed points within the surveyed 


\section{ACCEPTED MANUSCRIPT}

zone and faults (blue histogram) for the whole Sea of Marmara, and for the Western High (WH) and Central High $(\mathrm{CH})$ zones indicated in Figure 1.

Figure 6: Cumulative distribution function of minimum distance to faults for a uniform random distribution generated over the domain covered (black) and for the observed acoustic anomaly distributions over the domain covered (magenta), over the Central High zone (blue) and over the Western High zone (red). Exponential fits of the cumulative distributions are indicated as dashed lines

Figure 7: Fault and acoustic anomaly maps. (A): General fault map after Şengör et al. (2014) with location of AUV survey; confirmed active faults are indicated in red, blind or inactive faults are indicated in black. (B), (C) and (D): detailed maps of the seafloor deformation zone around the Main Marmara Fault based on AUV mapping (Grall et al., this issue) and acoustic anomalies (in blue) (Dupré et al., 2015). Faults scraps are indicated in red; fold axes and gravity driven deformation (slump scars and waves) in black. (B) Cinarcik Basin, dashed red line is a presumed inactive fault trace along the base of the cliff (see text); (C) Western High, dashed red lines are buried faults, presumably inactive today; (D) Central High.

Figure 8: Probable gas migration pathway in core MRS-CS22 (see location in Figure 3). The black vein in the core is a $60 \mathrm{~cm}$ long fracture with iron monosulfide fill. The section at $55 \mathrm{~cm}$ (8.04 $\mathrm{m}$ from core top) shows that the structure is planar. The iron monosulfides cause a large magnetic susceptibility anomaly that does not relate with sedimentary layering. The upper tip of the crack is surrounded with a black halo formed by methane diffusion into the sediment and reaction with sulfate present in the pore water.

Figure 9: Sub-parallel small cracks observed in core MRS-CS22 (see location in Figure 3) at $9 \mathrm{~m}$ depth (section 10). The cracks originally contained iron monosulfides that were oxidized to iron hydroxides (brown color) while the core was stored, before opening and splitting. Most of the monosulfides patches within the mud in this section were not oxidized. The cracks have a 1-3 cm size and the initial presence of monosulfides suggests they hosted methane. The cracks here shown are inferred form a connected network as they allowed oxygen entry from the edges of the core. 


\section{ACCEPTED MANUSCRIPT}

Figure 10: Schematic diagrams representing processes of gas migration through tensile cracks in shallow sediments opening as a consequence of (A) tensile state of stress at the seafloor along an anticline crest and associated with slope instabilities (B) opening of cracks parallel to the maximum principal stress associated with buried slip along a fault. Preferential crack orientation leads to gas expulsion at the seafloor forming parallel curtains of bubbles, as observed during submersible dives in Cinarcik Basin (Grall et al., this issue; Henry et al., 2007).

Figure 11: Conceptual model of fluid migration in a strike-slip fault system. The generic structure shown includes an anticline, a basin scale negative flower structure, and fracture damage zones that broaden toward the seafloor forming kilometer scale deformation zones around the main faults. Blue arrows indicate gas migration pathways determined by sediment layering and the blue curve represents the distribution of gas emissions at the seafloor resulting from migration along these pathways, assuming fault zones are not influencing gas migration. It can be suggested that the Central High zone is in this condition. Red arrows represent fluid migration in permeable fault zones and the red curve the distribution of gas emissions when faults are channeling fluids, enhancing fluid emission at the seafloor in swaths about $2 \mathrm{~km}$ wide. It can be suggested that the Western High zone is in this condition. Observations in the Sea of Marmara suggest that fault creep effectively maintains a high permeability in fault zones, while inter-seismically locked faults self-seal in 200 years at most. 


\section{ACCEPTED MANUSCRIPT}
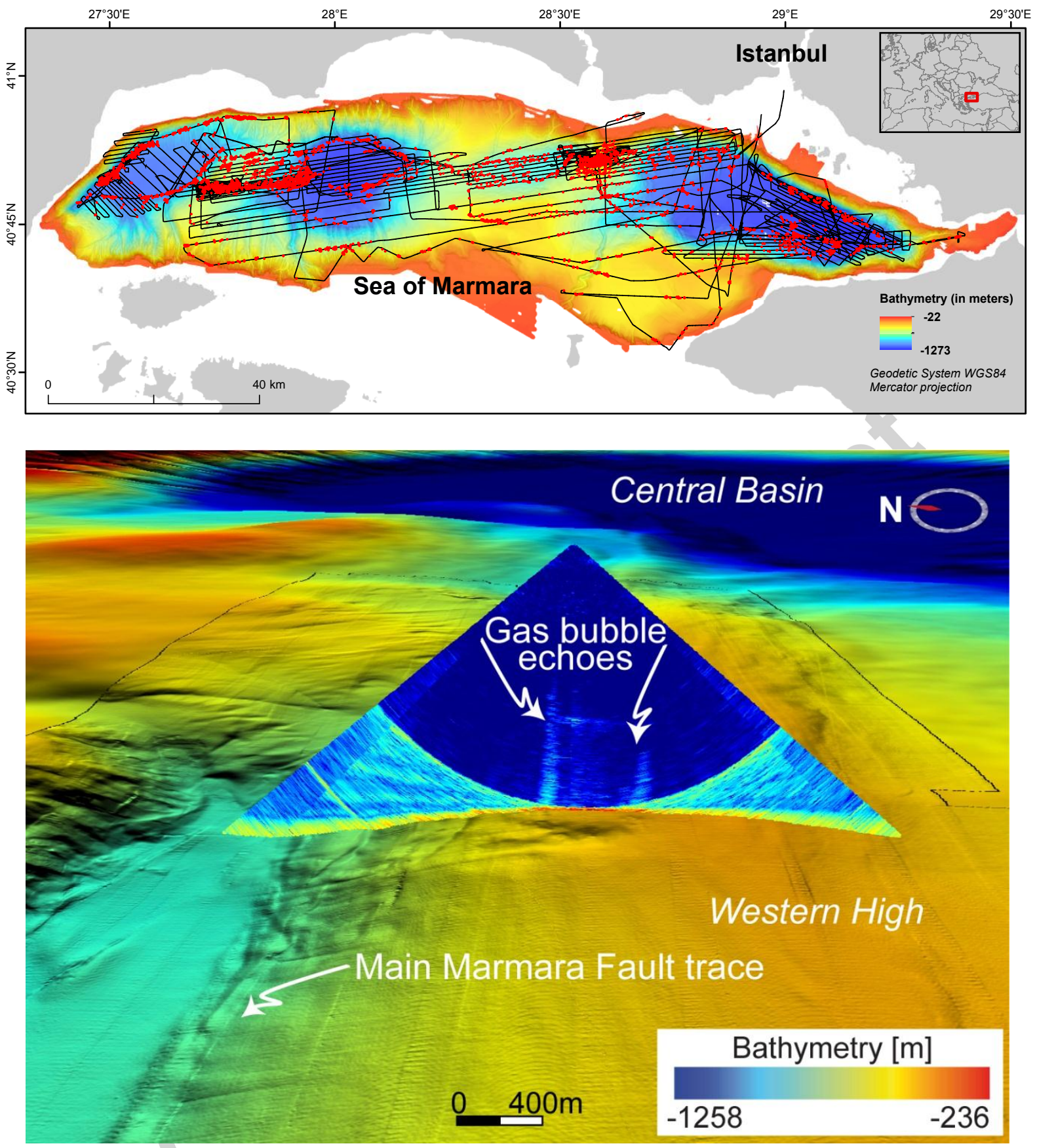

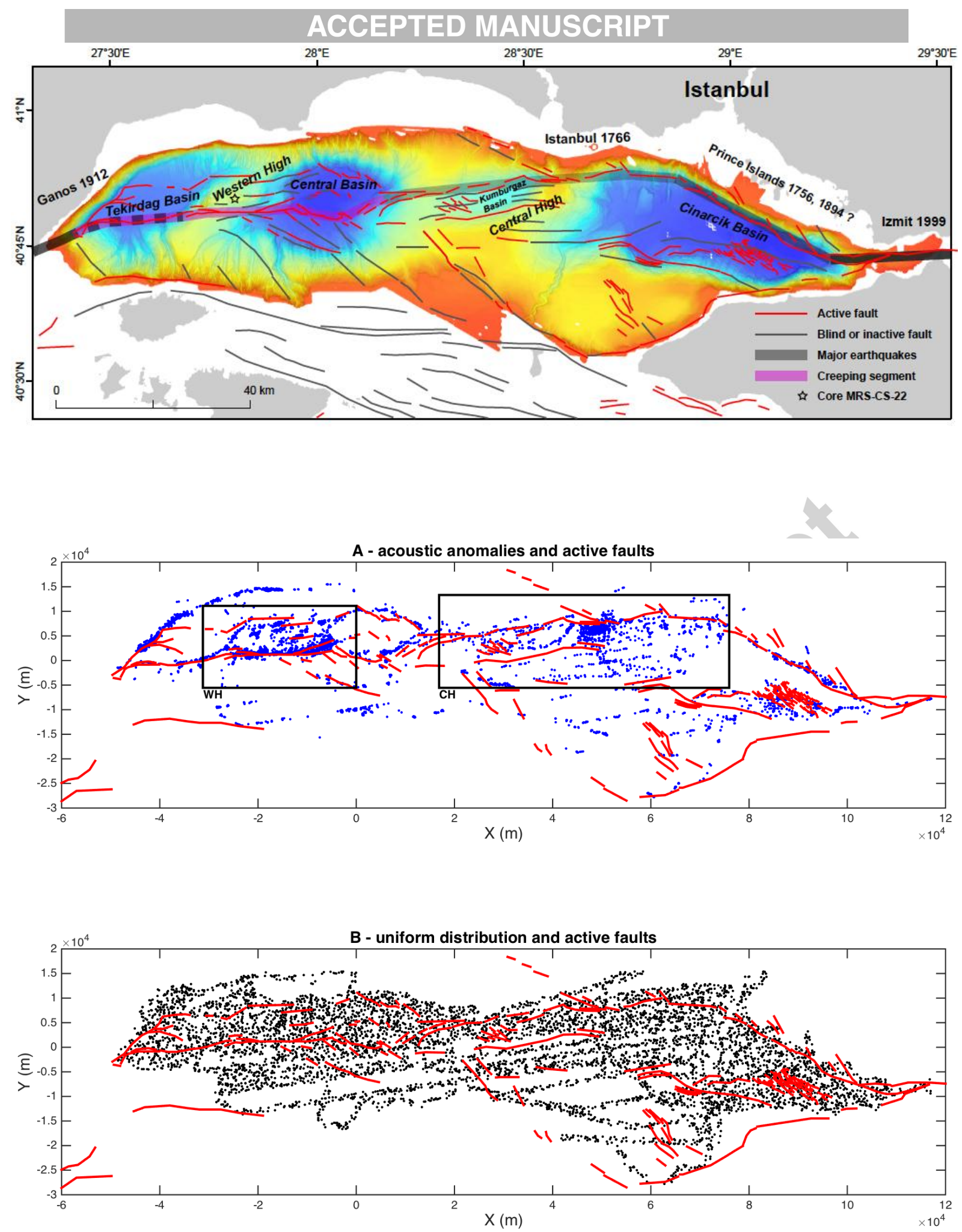

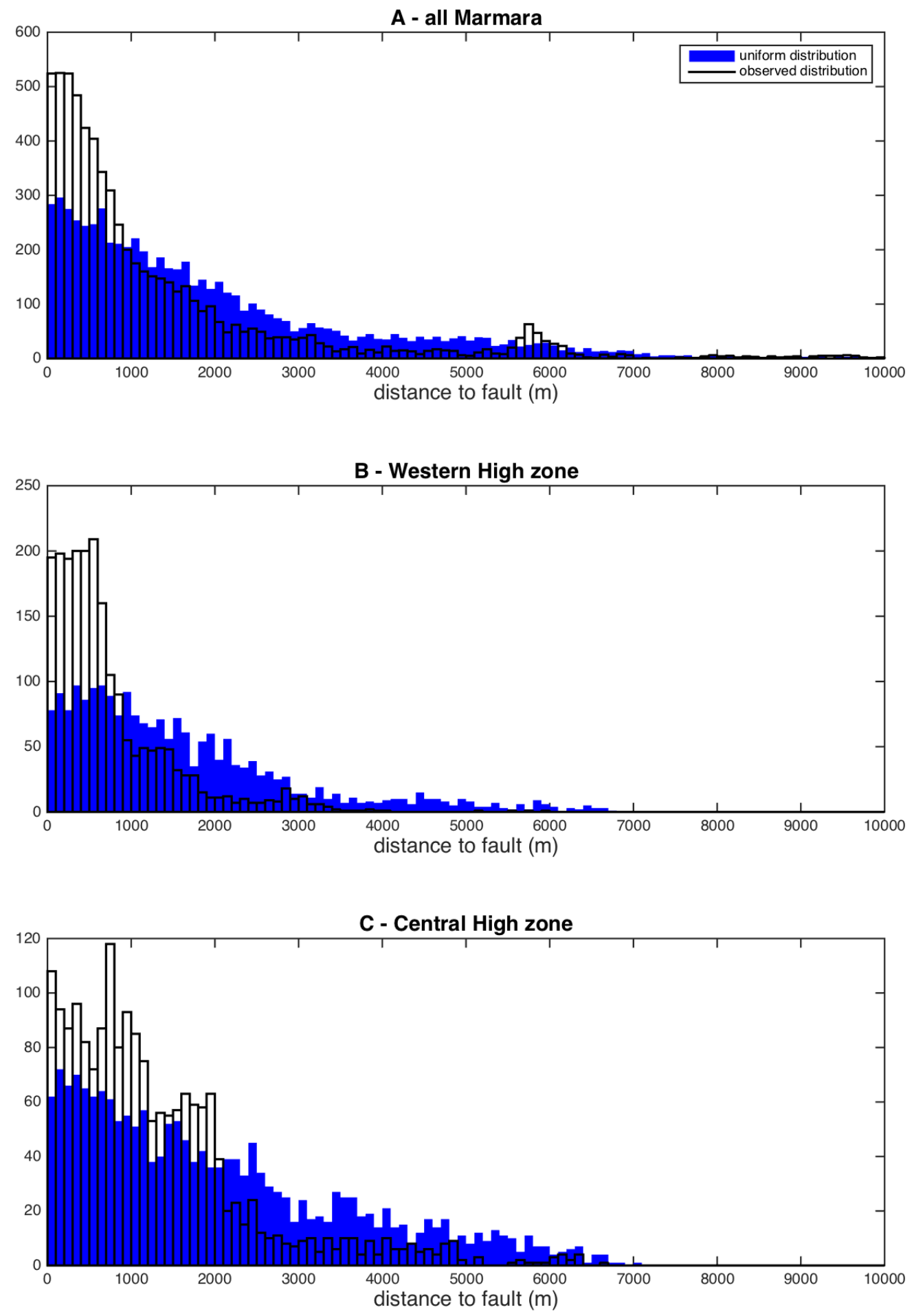


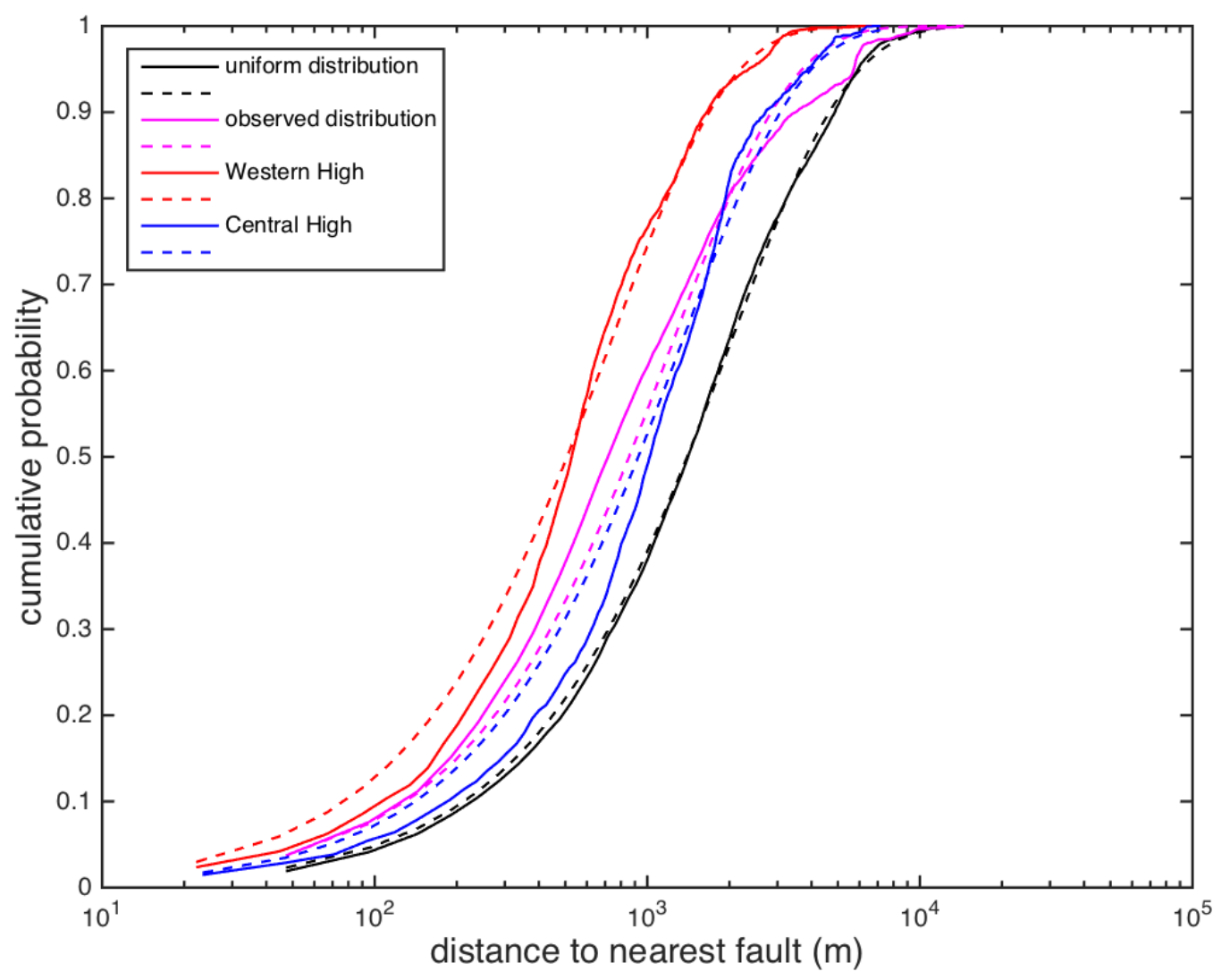




\section{ACCEPTED MANUSCRIPT}
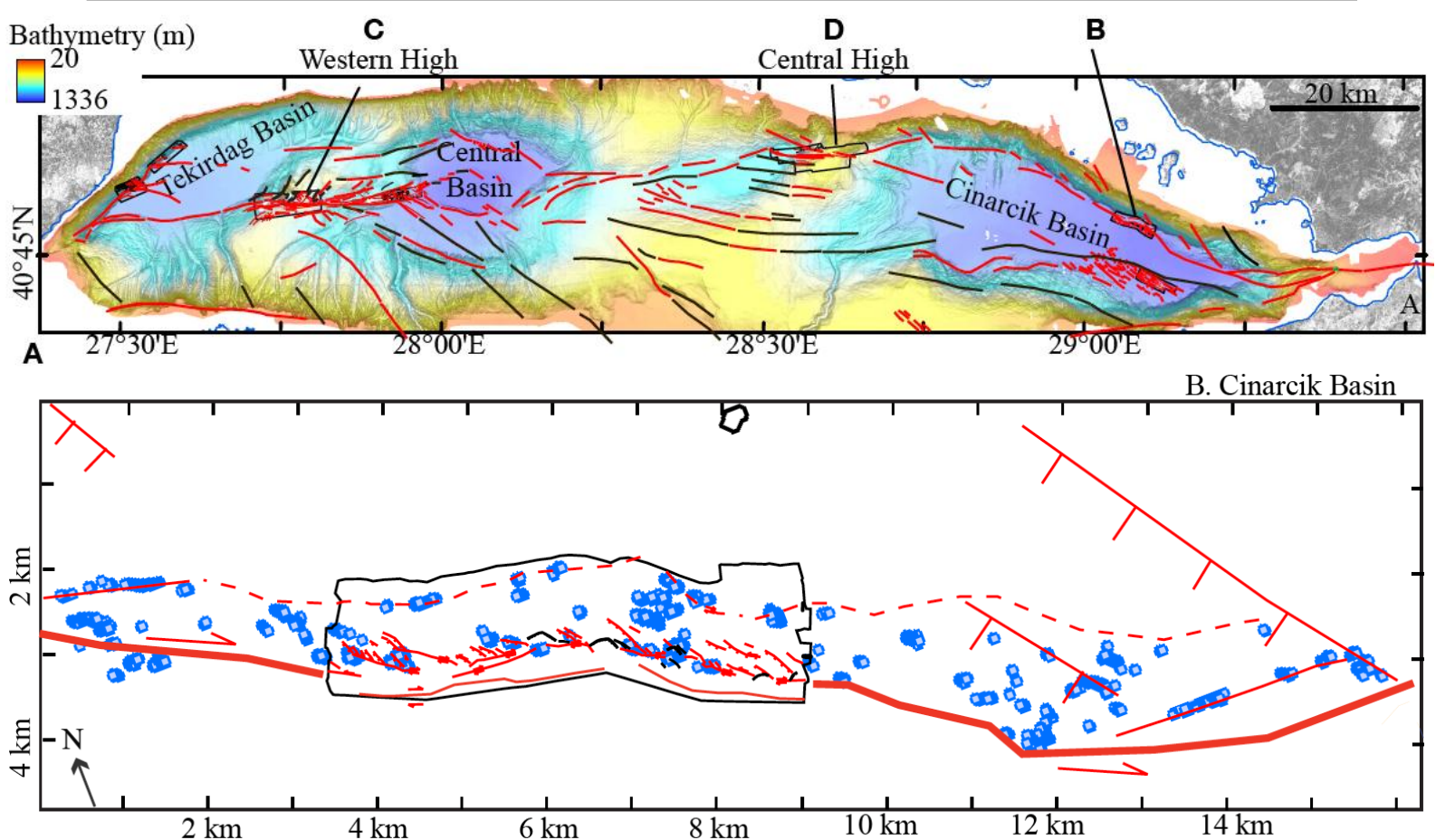

C. Western High

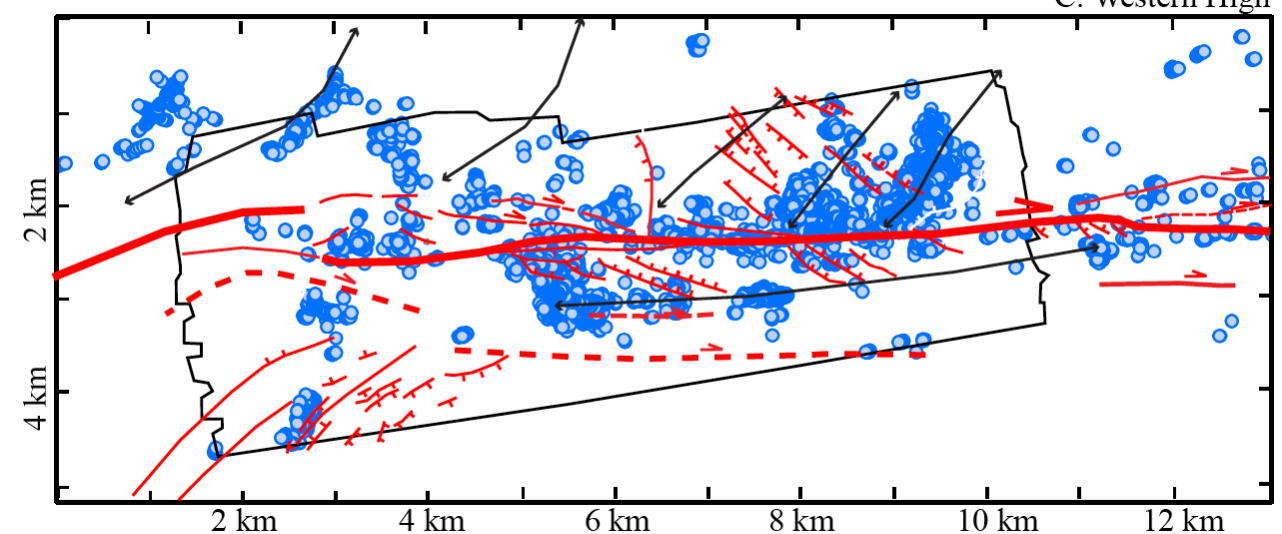

D. Central High

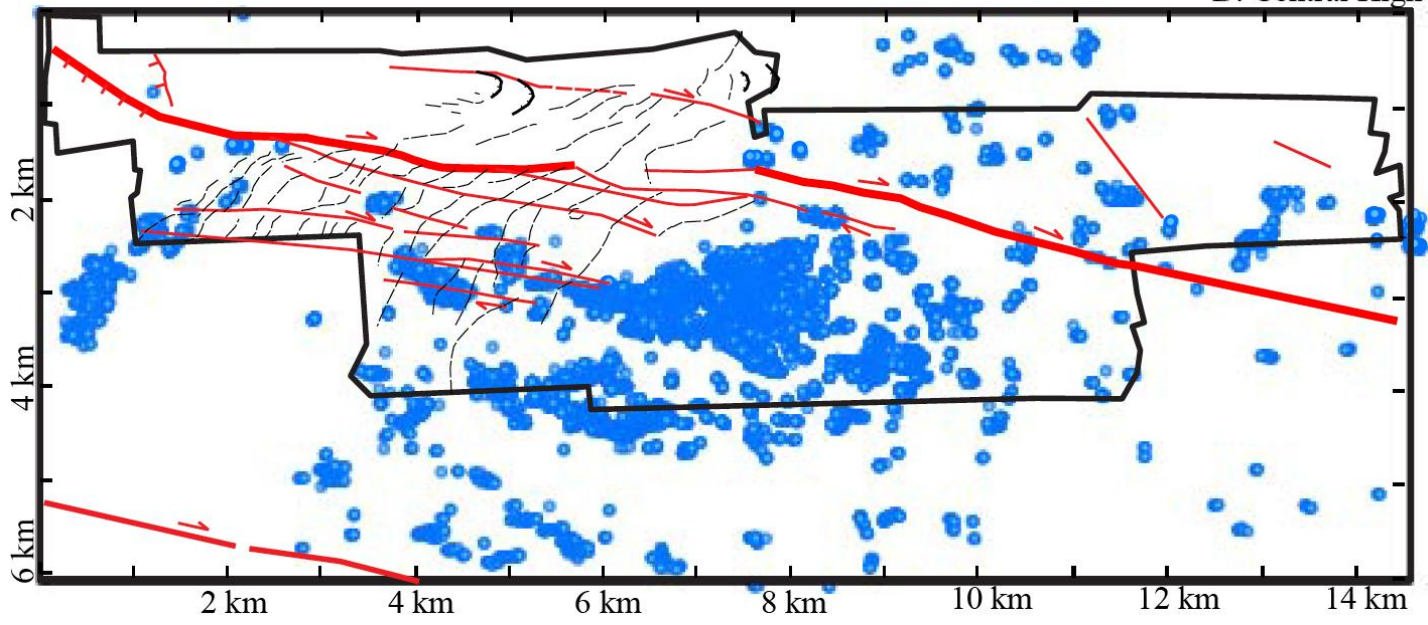




\section{ACCEPTED MANUSCRIPT}

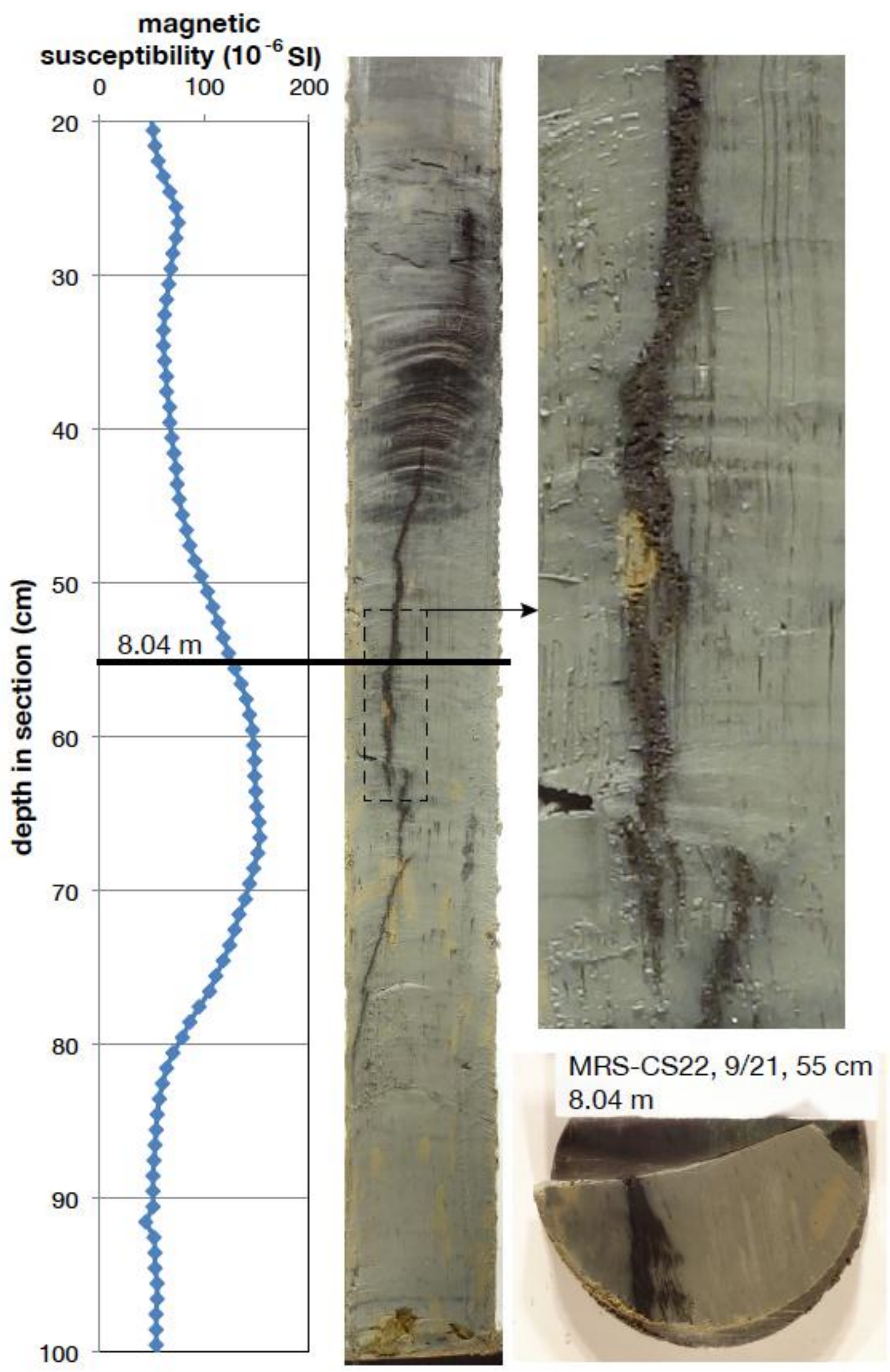




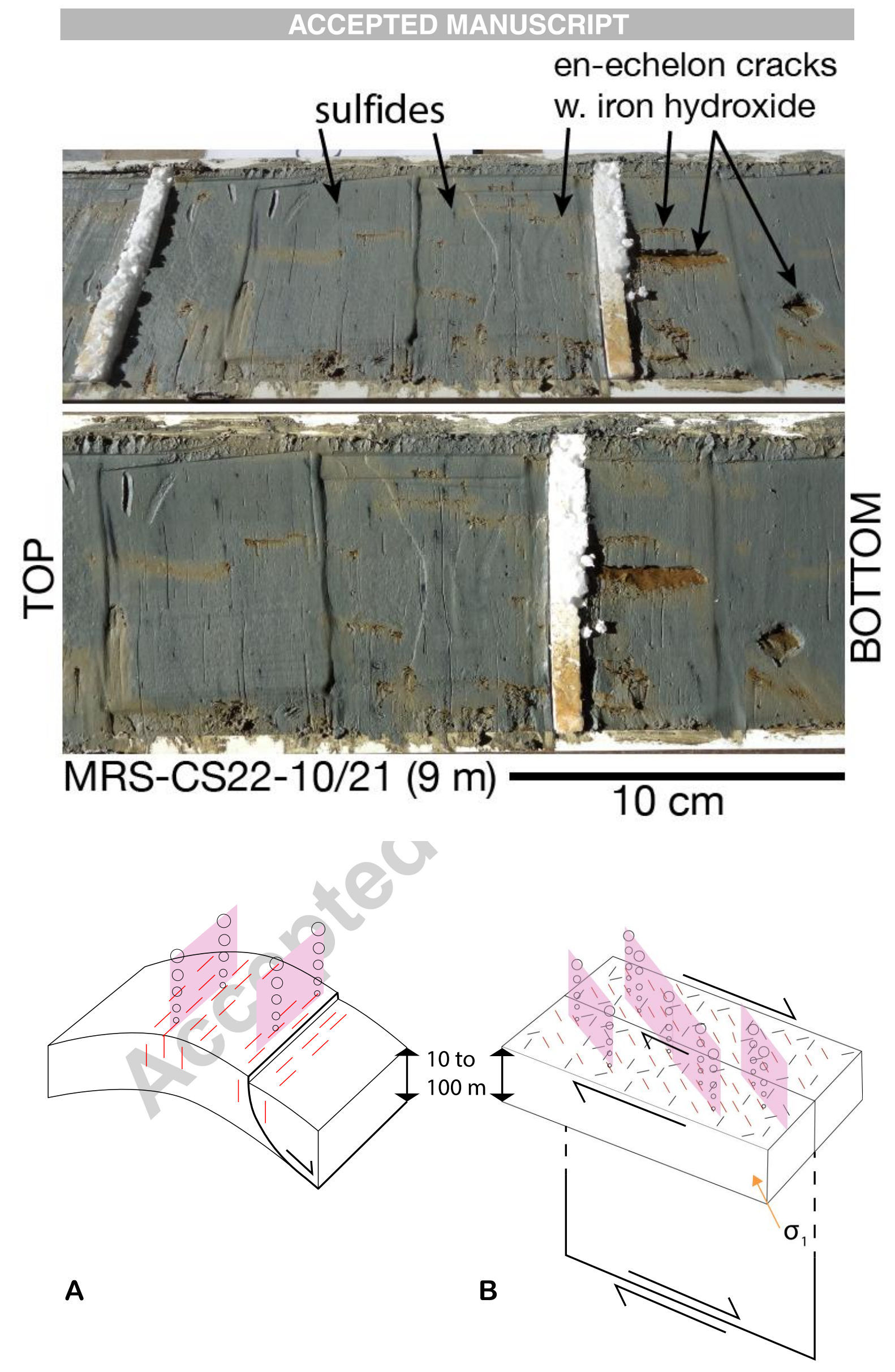




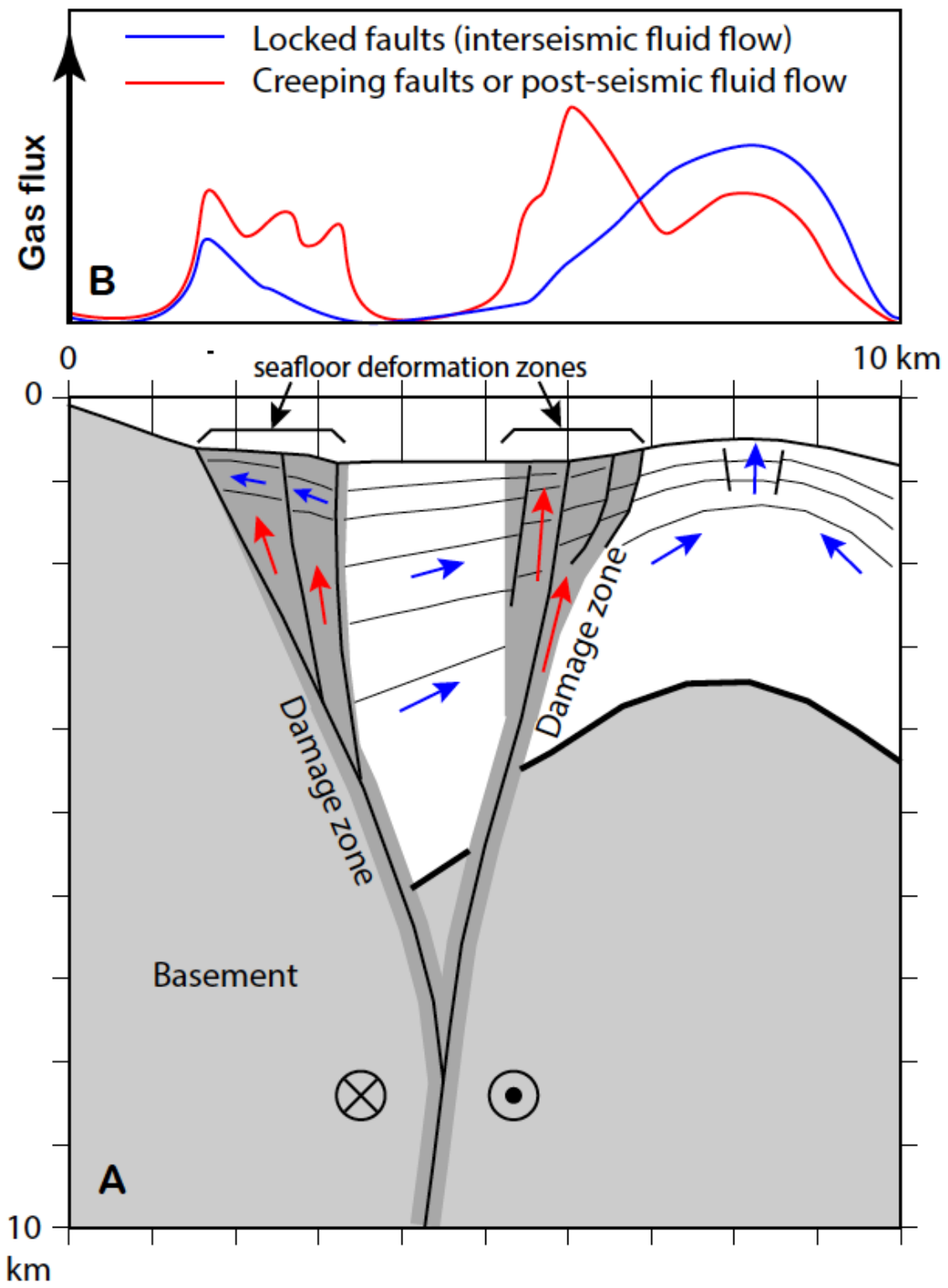

